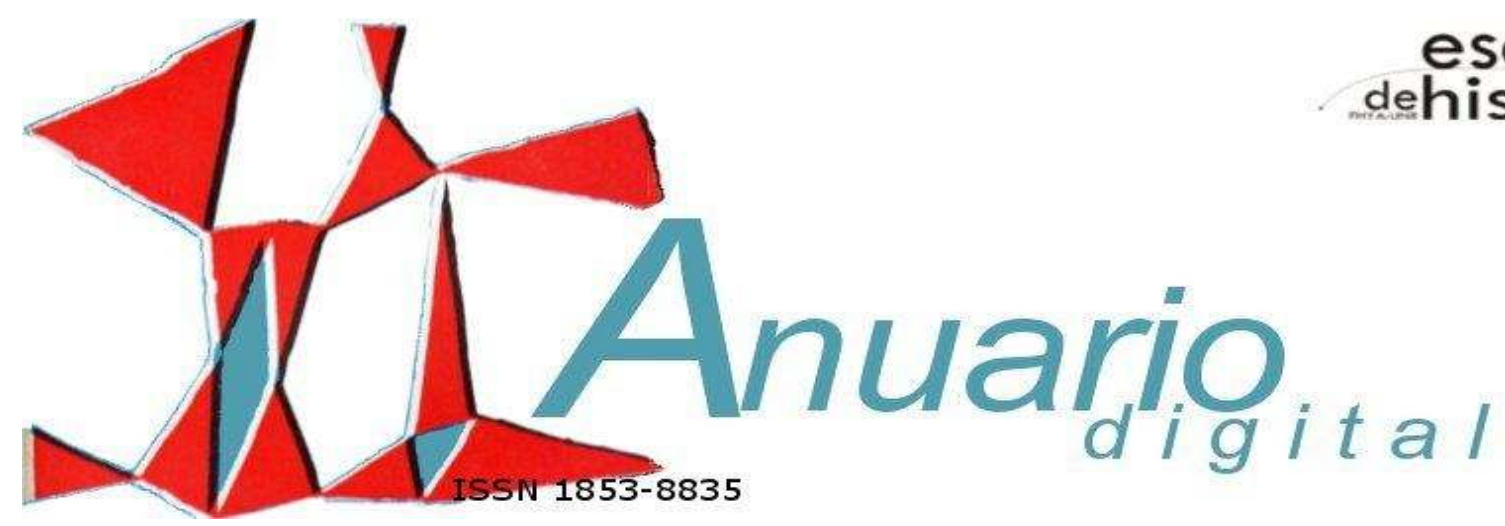

\title{
LA DIMENSIÓN ESPECTACULAR DE LA CALLE EN LA CIUDAD POSMODERNA: EL PASEO SANTA LUCÍA (MONTERREY, NUEVO LEÓN)
}

JOSÉ MANUEL PRIETO GONZÁLEZ

Universidad Autónoma de Nuevo León (Monterrey, México); jmpg71@hotmail.com

La cultura posmoderna ha venido estimulando un modelo de ciudad en el que el atractivo, la magia y la capacidad de seducción estética son claves como herramienta de beneficio económico. El criterio estético y la magia remiten a lo espectacular, y el espectáculo -indisociable ya de las sociedades actuales-, se sustenta básicamente en la imagen (apariencia), con frecuencia aparatosa u ostentosa, que se ofrece a la vista para diversión, deleite o asombro de los espectadores, en este caso ciudadanos y turistas. Con la intención de posicionarse globalmente, muchas ciudades del mundo están implementando políticas urbanas que fomentan proyectos espectaculares cuya recepción por parte de la ciudadanía suele ser bastante acrítica. Como parte de una investigación más amplia que propone una revisión multidisciplinaria de lo urbano desde la calle, este artículo aborda el estudio de una calle de Monterrey (Nuevo León, México) tan atípica como espectacular: el Paseo Santa Lucía. El éxito social y popular de este espacio público es incuestionable, pero no podemos permitir que la presencia deslumbrante de la obra anule nuestra capacidad crítica. Sobre todo porque es preciso alertar contra los riesgos que implica acomodar las políticas urbanas a las exigencias del espectáculo.

Palabras clave: Calle - sociedad del espectáculo - cultura posmoderna - urbanismo - Monterrey (Nuevo León, México) 
The postmodern culture has been stimulating a model city in which the attraction, magic and ability of aesthetic seduction are key as a tool for economic benefit. The aesthetic criteria and the magic refer to the spectacular, and the show -inseparable of the current societies-, is essentially based on the image (appearance), often showy or ostentatious, visible offered for fun, pleasure or astonishment of the spectators, in this case citizens and tourists. In order to position itself globally, many cities of the world are implementing urban policies that encourage spectacular projects whose reception by the citizens is often quite uncritically. As part of a larger research that proposes a multidisciplinary review of the urban from the street, this article deals with the study of a street in Monterrey (Nuevo Leon, Mexico) as unusual as it is spectacular: Paseo Santa Lucia. The social and popular success of this public space is unquestionable, but we cannot allow that the dazzling presence of the work cancel our critical capacity. Especially since it is necessary to warn against the risks that imply to accommodate the urban policies to the demands of the show.

Key words: Street - show society - postmodern culture - urban planning - Monterrey (Nuevo Leon, Mexico)

\section{Introducción}

El presente estudio se inscribe en el marco de un proyecto de investigación más amplio, centrado en el análisis de la ciudad y el espacio público, que propone una revisión multidisciplinaria de lo urbano desde la calle a partir del caso de Monterrey. El estudio del Paseo Santa Lucía tiene por objeto indagar en qué medida y de qué manera refleja la ciudad posmoderna las características de la sociedad del espectáculo de nuestro tiempo, planteando a su vez las consecuencias de unas políticas públicas que fomentan -con frecuencia acríticamente- actuaciones urbanísticas espectaculares, a veces excesivas. En el transcurso de la investigación fueron surgiendo diversos interrogantes: ¿es posible entender el Paseo Santa Lucía como una calle? ¿Justifican los antecedentes históricos esta actuación posmoderna en términos de identidad? ¿Es prioritario un proyecto así en una ciudad como Monterrey? ¿A qué lógica de necesidad responde? ¿Qué papel juega aquí el poder político? ¿Dónde radica el carácter posmoderno del proyecto? ¿Hubo alternativas al Paseo Santa Lucía? Para tratar de arrojar luz sobre estas y otras cuestiones manejamos principalmente documentación de archivo y bibliografía, así como la opinión de los usuarios de este espacio urbano.

\section{4}

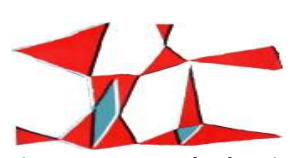

Anuario № 25, Escuela de Historia

Revista Digital № 4, Facultad de Humanidades y Artes, Universidad Nacional de Rosario, 2013 ISSN 1853-8835 
Tomando como referencia la distinción que propusiera Henri Lefebvre entre la ciudad y lo urbano ${ }^{1}$, el interés se centra aquí en lo primero, o más concretamente en la condición física y material de la calle, entendida como marco o escenario que ampara el desarrollo de la vida urbana. Pero es evidente que la ciudad no es autosuficiente en términos de significado; los objetos que la componen no pueden entenderse sin los sujetos que los producen y los usan. El sentido simbólico que los ciudadanos otorgan a menudo a determinados objetos e infraestructuras será fundamental a este respecto. En definitiva, la ciudad pierde sentido sin la experiencia urbana: sin ciudadanos no hay ciudad.

Ahora bien, no es menos cierta la insuficiencia de lo urbano con respecto a la ciudad, pues sin esta las interacciones sociales serían más primarias, menos complejas. El trazado y la arquitectura de las ciudades -los elementos físicos- condicionan las prácticas y experiencias urbanas de la gente. El flâneur o paseante, protagonista indiscutible del ambiente urbano decimonónico, hizo de la ciudad su escenario. Se ha dicho que sin él no existirían las arcadas parisinas, y sin las arcadas y los grandes bulevares -con sus enormes aceras- no existiría el flâneur. ${ }^{2}$ Para Morin, sujeto y objeto son inseparables, porque "no hay objeto si no es con respecto a un sujeto (que observa, aísla, define, piensa) y no hay sujeto si no es con respecto a un ambiente objetivo (que le permite reconocerse, definirse, pensarse, etc.). El objeto y el sujeto, librados cada uno a sí mismo, son conceptos insuficientes". ${ }^{3}$

Teniendo en cuenta el pensamiento del ingeniero y urbanista catalán Ildefons Cerdà, que entendió las calles como "medios de cultura y prosperidad social"4, se abordará el estudio del Paseo Santa Lucía en tanto producto histórico y cultural. Para ello, echo mano de la categoría cultural de posmodernidad como herramienta de análisis, aun cuando haya sido la modernidad (industrial) el marco primordial de referencia del desarrollo alcanzado hasta hoy por Monterrey. De hecho, aún perviven en la ciudad muchos aspectos culturales de raigambre moderna. Conviene aclarar que lo posmoderno no se identifica necesariamente con lo posindustrial. Lyotard asoció posmodernidad y posindustrialismo, ${ }^{5}$ pero Bell considera erróneo este vínculo al entender que lo posindustrial remite a cambios en las dimensiones técnica y económica de la

\footnotetext{
${ }^{1}$ Lefebvre, Henri; El derecho a la ciudad; Península; Barcelona; 1978.

${ }^{2}$ Amendola, Giandomenico; La Ciudad Postmoderna; Celeste; Madrid; 2000; p. 190.

${ }^{3}$ Morin, Edgar; Introducción al pensamiento complejo; Gedisa; Barcelona; 2005; pp. 66-67.

${ }^{4}$ Tarragó, Salvador; "Cuatro ciudades comparadas: Barcelona, Buenos Aires, Chicago y Kioto, o el arte del reconocimiento de los espacios antrópicos"; en Magrinyà, Francesc y Tarragó, Salvador (dirs.); Cerdà: ciudad y territorio. Una visión de futuro (catálogo de exposición); Electa; Madrid; 1998; p. 299.

${ }^{5}$ Lyotard, Jean-François; La condición postmoderna; Cátedra; Madrid; 1984.
}

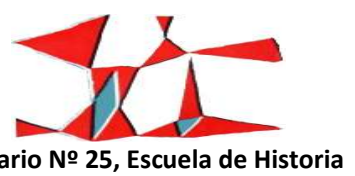


sociedad, y que lo tecnológico no compromete forzosamente a lo cultural, ámbito en que se desenvuelve el concepto de posmodernidad. ${ }^{6}$ La persistencia de la modernidad en Monterrey es alentada sobre todo por el notable peso que mantiene todavía el sector secundario o industrial en el conjunto de las actividades económicas del área metropolitana, aun cuando el sector terciario sea ya dominante en términos de empleo ${ }^{7}$. Lo anterior se traduce en una imagen urbana abrumadoramente moderna ${ }^{8}$, de la que solo escapan paisajes posmodernos como los de Barrio Antiguo, el Parque Fundidora y el propio Paseo Santa Lucía, entre otros $^{9}$. Sin embargo, es preciso reconocer que Monterrey ha venido transformándose, no solo porque avanza hacia la consolidación de una sociedad terciarizada, sino también porque buena parte de los esquemas mentales y culturales de la población son ya posmodernos, como demuestra, por ejemplo, su apego a los patrones consumistas, considerados sobre todo desde enfoques como el de Bauman. ${ }^{10}$

Más lenta ha sido la expresión de lo posmoderno en clave urbanística y arquitectónica, quedando reducida casi a los espacios más simbólicos -especialmente desde el punto de vista histórico- de la ciudad, a eso que Amendola ha dado en llamar "ciudad imaginaria", que no es sino la porción más vendible de la ciudad en términos turísticos y de atracción de inversiones. ${ }^{11}$ El Paseo Santa Lucía refleja bien el empeño de los políticos locales por sumarse a una corriente global que se sirve de la seducción estética como herramienta de beneficio económico, es decir, como instrumento esencial para transformar las ciudades y solucionar sus problemas.

Con este objeto de estudio, que remite a usos de la calle ligados al esparcimiento y a lo lúdicorecreativo, además de a una idea del andar como "práctica estética"12, la presente investigación acusa igualmente interés por otros temas: 1) la apropiación del espacio público, que no solo implica aquí a la

\footnotetext{
${ }^{6}$ Bell, Daniel; "Epílogo de 1996 a Las contradicciones culturales del capitalismo"; en Beriain, Josetxo y Aguiluz, Maya (eds.); Las contradicciones culturales de la modernidad; Anthropos; Barcelona; 2007; pp. 63-64.

${ }^{7}$ Según el Censo Económico del INEGI correspondiente a 2009, la producción brutal total (en miles de pesos) del área metropolitana de Monterrey (AMM) en relación al sector terciario (comercio y servicios), ascendió a \$314,080,693.00, mientras que la aportación del sector secundario (minería, energía, construcción, industrias manufactureras) fue de $463,613,345.00$. En cuanto a personal ocupado, el sector secundario dio empleo (en el conjunto del AMM) a un total de 386,616 personas, frente a las 742,567 del sector terciario.

${ }^{8}$ Que se expresa a través de infinidad de postes y cables eléctricos, mantenimiento de complejos de industria pesada y chimeneas humeantes, vías férreas que siguen atravesando muchas calles, trenes de mercancías que interrumpen el tráfico automovilístico, total predominio de la calzada asfáltica en detrimento de las aceras ( $y$, por extensión, del coche frente al peatón), etc.

${ }^{9}$ Prieto González, José Manuel; "La consolidación del Monterrey imaginario en el contexto de la globalización: macroproyectos urbanos"; en Frontera Norte; v. 23; N. 45 (enero-junio de 2011); pp. 163-192.

<http://aplicaciones.colef.mx:8080/fronteranorte/articulos/FN45/6-f45.pdf>.

${ }^{10}$ Bauman, Zygmunt; Amor líquido. Acerca de la fragilidad de los vínculos humanos; Fondo de Cultura Económica de Argentina; Buenos Aires; 2005.

${ }^{11}$ Amendola, Giandoménico; La ciudad posmoderna; Ob. Cit.

${ }^{12}$ Careri, Francesco; El andar como práctica estética; Gustavo Gili; Barcelona; 2002.
}

146

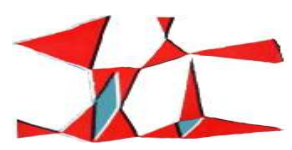

Anuario № 25, Escuela de Historia

Revista Digital № 4, Facultad de Humanidades y Artes, Universidad Nacional de Rosario, 2013 ISSN 1853-8835 
ciudadanía -o a parte de ella-, sino también a los gobernantes; 2) los procesos de transformación de la ciudad, en este caso a través de prácticas de valoración del patrimonio urbano y políticas de control de la imagen urbana; y 3) la identificación del componente ideológico en el espacio urbano, relacionado aquí con la idea tradicional de grandeza y con la manera en que las dos grandes formaciones políticas locales (PRI y PAN) entienden -en el marco de la lucha partidista- la idea de hacer ciudad, que en realidad remite a un mismo modelo, traído de fuera y regido por preocupaciones estéticas más que ético-sociales.

\section{Una calle atípica}

Atípica o especial. De hecho, el Paseo Santa Lucía ni siquiera merece la consideración de calle para la mayor parte de la ciudadanía. Así lo revela el resultado de una pregunta formulada a usuarios del Paseo en el marco de un sondeo de opinión llevado a cabo en marzo de $2011^{13}$. La cuestión se planteó en los siguientes términos: "Desde su perspectiva, ¿es posible entender el Paseo Santa Lucía como una calle? En caso negativo, defina cómo entiende usted este espacio público". Las respuestas no dejan lugar a dudas: el 88.5\% (62 de 70 encuestados) estimó que el Paseo no era una calle. Ahora bien, al tener que identificar ese espacio de otra manera, nos encontramos con que muchas de las definiciones dadas no son incompatibles con la idea general de calle. Así, por ejemplo, se ve el Paseo como "un lugar donde hay mucha gente", "un lugar para andar libremente", "un espacio de distracción familiar", "un espacio de recreación", "un espacio del pueblo", "un lugar para toda la gente", "un lugar de convivencia", etc. ¿Hay algo en los enunciados anteriores que sea ajeno a una verdadera calle? Es más, ¿no debería entenderse la calle en esos términos, es decir, como lugar de convivencia, de recreo, de libre paseo? Algún encuestado puso en duda que fuese una "calle pública", y esa duda está justificada en parte, dado que un sector del Paseo, el que discurre desde la avenida Félix U. Gómez hacia el oriente, adentrándose en el Parque Fundidora, tiene horarios de apertura y cierre, además de elementos de control como rejas y puertas (Imagen 1). Ese tramo, por tanto, sería en todo caso semipúblico, cuando la condición de calle -entendida como espacio público- debe ser permanente. De ahí la diferencia con las calles internas de los centros comerciales, por más que estas estén suplantando a las calles de la ciudad como lugares de encuentro y convivencia.

\footnotetext{
${ }^{13}$ La encuestadora fue la Lic. en Psicología Ana Luisa González Rosas, becaria del proyecto de investigación en el que se inscribe este estudio. El cuestionario, conformado por 21 preguntas, se aplicó a un total de 70 personas a lo largo de una semana (10 personas por día de la semana), del 14 al 20 de marzo de 2011, en distintos puntos del Paseo Santa Lucía. El 66\% de los encuestados fueron varones (46) y el 34\% restante, mujeres (24). La edad de los encuestados abarca desde el rango de "15 a 20 años" hasta el de "51 en adelante". La muestra se decidió por saturación. Las preguntas principales revelan una tendencia uniforme.
}

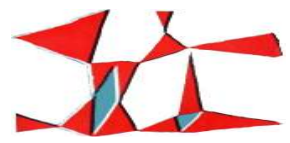

Anuario № 25, Escuela de Historia 
¿Qué se deduce de las respuestas anteriores? Varias cosas. En primer lugar, si el Paseo Santa Lucía no tiene atributos de calle, se nos está diciendo indirectamente cómo son en realidad las calles de Monterrey, de qué adolecen o en qué son deficitarias. Se nos dice, asimismo, que el regiomontano posmoderno sigue entendiendo la calle en clave moderna, es decir, casi exclusivamente como lugar de tránsito o trasiego de vehículos - sin asomo apenas de peatones- y como superficie asfaltada. Un reciente artículo de Milenio (edición Monterrey), que denuncia el peligro que ronda a los ciclistas de la ciudad, revela precisamente que muchos conductores sienten que las calles deben ser solo para los vehículos automotores, y ven como un problema las bicicletas. ${ }^{14}$ Además, el mal estado en que se encuentran las banquetas, cuando existen, confirma que esa calle que es reconocida como tal por una mayoría de ciudadanos no es apta para el paseo o los desplazamientos a pie; calle no es aquí sinónimo de paseo. La modernidad ortodoxa, tal como fue entendida en las primeras décadas del siglo XX por las vanguardias históricas del Futurismo y el Estridentismo, instó a desechar las aceras. ${ }^{15}$ La prioridad conferida al arroyo asfaltado de la calle sobre las aceras supuso una clara legitimación del coche y de su conductor en detrimento del peatón y del antimoderno -por obsoleto- acto de caminar. El automóvil sigue siendo en Monterrey amo y protagonista absoluto de las calles, y esto se aprecia incluso en la ficción literaria; basta leer la novela The Monterrey News (1990), de Hugo Valdés. Esta ciudad encaja perfectamente en lo que denomina "la ciudad de los coches" ${ }^{16}$, orientada a conseguir que la gente se mueva en sus vehículos; estos y el espacio urbano aparecen como "objetos sociales interactuantes". Existe aquí toda una cultura del carro, muy influida por lo texano-norteamericano, que expresa bien el impacto de la motorización en la construcción de representaciones sobre los ideales del individualismo y la identidad, así como del urbanismo y la modernización. Por tanto, es comprensible, dentro de esta lógica cultural, que una arteria espectacular y pensada para caminar como el Paseo Santa Lucía escape a lo que el imaginario local entiende por calle. Lo cual revela, asimismo, la excepcionalidad del Paseo en relación al resto de calles de la ciudad, de la "ciudad real".

\footnotetext{
${ }^{14}$ Mendoza, Daniela; "El peligro ronda a los ciclistas de la ciudad", en Milenio (edición Monterrey); domingo 21 de julio de 2013; sección "El tema"; pp. 6-7.

${ }^{15}$ Sant'Elia, Antonio, y Marinetti, Filippo T.; “Manifiesto de la Arquitectura Futurista [1914]”; en Conrads, Ulrich (ed.); Programas y manifiestos de la arquitectura del siglo XX; Lumen; Barcelona; 1973; p. 56.

${ }^{16}$ Buxó, M. a Jesús; “La ciudad de los coches” ; en Calatrava, Juan y González, José A.; La ciudad: paraíso y conflicto; Abada; Madrid; $2007 ;$ p. 77.
}

148

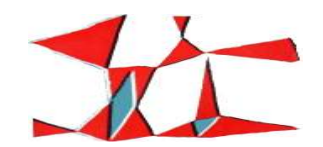

Anuario № 25, Escuela de Historia

Revista Digital № 4, Facultad de Humanidades y Artes, Universidad Nacional de Rosario, 2013 ISSN 1853-8835 
El Paseo Santa Lucía no surge de la nada. Como veremos en el apartado siguiente, vino a sustituir a una calle anterior -Domingo Gayosso-, que a su vez se impuso sobre la antigua acequia de Guadalupe. Aun así, hay que asumir que estamos ante una calle especial. Pero las diferencias formales con las vías convencionales son menores de lo que pudiera parecer a primera vista, pues en ambos casos se percibe un espacio central destinado a la circulación de vehículos -lanchas o coches- y flanqueado por sendas aceras peatonales de anchura y composición variables. El contraste más notorio tiene que ver con la sustancia del cauce central, agua en un caso y asfalto en otro. Todo lo demás son afinidades. El canal del Paseo expresa mejor incluso que el asfalto el sentido primigenio del espacio de la calle, a pesar de que, a diferencia del antiguo canalón, ya no sea una corriente fluvial propiamente dicha. Ese sentido original de la calle se relaciona con su principal uso o función, la de circulación o tránsito -tanto peatonal como vehicular-, que apela a algo puramente instrumental, práctico, a un ir de acá para allá, a un desplazamiento fluido entre dos puntos. Aunque la calle es un espacio de uso polivalente, esa es la manera elemental de usarla. Rige aquí la dinámica de flujos, la física de fluidos, la lógica orgánica de los seres vivos. De ahí que el término "arteria" permita definir tanto el vaso o torrente que lleva la sangre desde el corazón a las demás partes del cuerpo, como la calle "a la cual afluyen muchas otras". Y la primera acepción de "avenida" que ofrece el diccionario oficial del castellano habla de "creciente impetuosa de un río o arroyo". Es más, el modo tradicional de describir la calle distingue claramente entre el arroyo central y las banquetas o aceras laterales. Es significativo comprobar qué poco cambian las cosas entre un tipo de calle y otro cuando se ven circulando por el canal patrullas náuticas de policía (Imagen 2). Téngase en cuenta, por otra parte, que la calle no solo se identifica con una vía de tránsito o circulación, no solo es un espacio determinado por decisiones sobre la vialidad y los usos; también se define a partir de los edificios y vacíos urbanos -baldíos, plazas, jardines, etc.- que la delimitan.

Un paseo es una modalidad de calle que tuvo amplio desarrollo en el siglo XIX, en el marco cultural del Romanticismo. Con los paseos románticos se buscó satisfacer necesidades de salubridad e higiene, pero también estéticas y de recreo o esparcimiento público -conectadas en cierto modo con la salud-. Apacibles y tranquilos, amenos y agradables, los paseos eran espacios "deliciosos" que procuraban "hermosura y distracción”. En ocasiones estaban muy bien equipados, pudiendo contar con jardines, arbolado, fuentes,

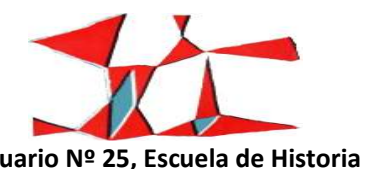


cascadas, estanques, pórticos y pabellones de diversa índole ${ }^{17}$. En torno a ellos y a su práctica se generó una verdadera cultura del paseo, entendida como una especie de arte del caminar (placentero). Algunos llegaron a convertirse en espacios representativos de la ciudad. Una figura emblemática asociada a los paseos decimonónicos es la del flâneur o paseante, que hizo de la calle-paseo el escenario perfecto en el que ver y ser visto. No conviene desdeñar, por tanto, esta conexión con el Romanticismo, entre otras cosas porque el diseño posmoderno de Santa Lucía tiene inequívocos ascendentes románticos.

Si hablamos de paseos en México, es obligado referirse al icónico Paseo de la Reforma de la capital del país. Creado a instancias del emperador Maximiliano (1864-67), y antes de convertirse en el corredor de rascacielos que conocemos hoy, fue un bucólico paseo concebido para ser "la avenida más bella de México". Monnet ha visto en él la "calle emblemática" de la ciudad, un "emblema de excepción" por su carácter extraordinario. ${ }^{18}$ El posmoderno y mágico Paseo Santa Lucía tiene también mucho de emblema y excepción; aunque no sea una vía de circulación al uso, es un singular corredor de esparcimiento que aspira a ser-si no lo es ya- representativo del espacio urbano, como revelan distintas fuentes iconográficas.

En Santa Lucía se revitaliza la práctica antimoderna del andar. Llama la atención, en relación a lo arcaico que les resultó a los modernos el acto de caminar, que un manifiesto urbanístico como la Carta de Atenas, inspirado por Le Corbusier en el marco del IV CIAM (1933), incluya las "calles de paseo" entre los cuatro tipos de vías contemplados, al tiempo que se reconoce la "recreación" como una de las funciones clave del ser humano. Pero esto no debe llevarnos a engaño: las calles de paseo no son una concesión exclusiva a los peatones, sino una sutil manera de permitir -al imponerse en ellas una velocidad reducidala mezcla de toda clase de vehículos con los peatones. Además, no se tardó mucho en plantear la posibilidad de realizar paseos en coche...

Con el tiempo, sin embargo, el andar llegará a verse incluso como práctica estética. En la década de 1960, coincidiendo con la aparición y desarrollo de corrientes como el minimalismo y el land art, el mundo del arte toma conciencia de la necesidad de salir de las galerías y los museos con el fin de reconquistar la experiencia del espacio vivido y de las grandes dimensiones del paisaje. La calle tuvo mucho que decir en el

\footnotetext{
${ }^{17}$ Nótense las similitudes con el equipamiento del Paseo Santa Lucía.

${ }^{18}$ Monnet, Jérôme; "La rue et la représentation de la ville: iconographie et lieux communs à Mexico et à Los Angeles"; Flux; 2006-2007/4-1; N 66/67; pp. 8-18.
}

150

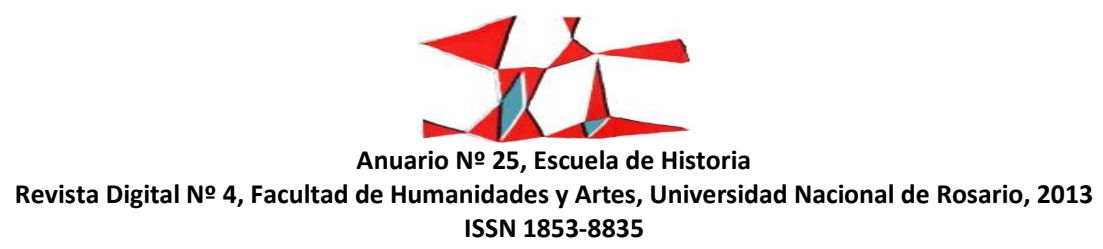


paso del objeto minimal a la experiencia sin objeto. El escultor estadounidense Carl Andre, que realizaba esculturas planas o espacios-objeto por los cuales era posible andar, señaló en una entrevista que para él la escultura ideal era una calle. Su colega Richard Long fue más allá: el arte que él concibió fue el propio acto de andar, el hecho de vivir esa experiencia, es decir, un arte que se materializaba andando ${ }^{19}$

\section{Recapitulación histórica: la fundamentación natural del Paseo Santa Lucía}

El topónimo Santa Lucía es anterior incluso al de Monterrey. En el acta fundacional de la ciudad, del que se ha reproducido un extracto a escala monumental en el lateral izquierdo de la explanada que se abre frente al Museo de Historia Mexicana, justo donde inicia el Paseo, se dice expresamente que Diego de Montemayor funda Monterrey un 20 de septiembre de 1596 "junto a un monte grande [cerro de La Silla] y ojos de agua que llaman de Santa Lucía". Si ya entonces llamaban así a los ojos de agua, es que alguien había puesto ese nombre con anterioridad. La de Montemayor fue la tercera y definitiva fundación, pero en la primera, auspiciada por Alberto del Canto en 1577, se crea un poblado al que se denomina Ojos de Santa Lucía, que fue por tanto el primer nombre de Monterrey. Pero, ¿por qué Santa Lucía? Algunas fuentes sitúan esa primera fundación el 15 de diciembre de 1577, pero si nos atenemos al llamado "Documento del Parral" (1643), que nos da el año pero no el mes ni el día del establecimiento oficial, parece lógico seguir a Eugenio del Hoyo cuando sugiere relacionar calendario y santoral. En efecto, era costumbre en aquella época poner a las nuevas poblaciones el nombre del santo del día de su descubrimiento o fundación, por lo que es probable, según Del Hoyo, ${ }^{20}$ que haya sido un 13 de diciembre, festividad de Santa Lucía. Es más, podría establecerse también una relación analógica entre la santa y el fenómeno natural de los ojos de agua, toda vez que en las representaciones iconográficas de esta "virgen y mártir" son habituales los ojos como atributos especiales.

Pero lo que interesa aquí son los ojos de agua de aquel primitivo Valle de Extremadura, soporte de un portentoso y casi paradisíaco sistema hidrológico conformado por ríos, arroyos, acequias y canales, del que ya no queda prácticamente nada. El actual canal artificial no es sino paráfrasis posmoderna del viejo canalón que empezó a construirse en el siglo XIX. El referido valle era bañado por dos ríos que corrían de poniente a oriente: el Santa Catarina y el de los manantiales de Santa Lucía. Este último fue descrito por

\footnotetext{
${ }^{19}$ Careri, Francesco; El andar como práctica estética; Gustavo Gili; Barcelona; 2002; pp. 121-124.

${ }^{20}$ Hoyo, Eugenio del; Historia del Nuevo Reino de León (1577-1723); ITESM / Fondo Editorial de Nuevo León; Monterrey; 2005 (1972); p. 83.

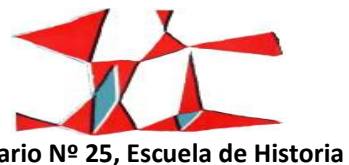
Revista Digital № 4, Facultad de Humanidades y Artes, Universidad Nacional de Rosario, 2013 ISSN 1853-8835
} 
Alonso de León en el siglo XVII como un caudal "tan abundante y rico, que en otra parte adquiriera nombre de caudaloso río". ${ }^{21}$ Pero, entre la documentación histórica disponible, es la cartografía la que permite hacerse una mejor idea de la evolución que conduce de los ojos de agua y el río Santa Lucía hasta el canal que vertebra hoy el Paseo homónimo.

El primer plano conocido de la ciudad, debido a José de Urrutia, data de 1767. En él se aprecia al norte de la todavía modestísima población una corriente fluvial que la delimita por ese rumbo: es el arroyo o río Santa Lucía. Aparte del cauce normal, se representa también el área sujeta a inundación, bastante amplia. La corriente se identifica por medio de una leyenda que reza "arroyo formado por varios ojos de agua", señalándose de manera específica uno de esos afloramientos hídricos, que, aunque aquí se presenta genéricamente como "pequeños manantiales", corresponde a lo que se conoció tradicionalmente como "ojo de agua de la ciudad" - u “ojo de agua grande"22-, simbólicamente recordado hoy en la Fuente Monterrey, en el cruce de las calles Zaragoza y Matamoros. La ciudad se veía ceñida no solo por el arroyo del norte, el río Santa Lucía, sino también por el aquí llamado "río de Monterrey" -actual Santa Catarina- en las zonas sur y oriental. El agua de esos ríos cubría las necesidades vitales de la población y permitía regar los campos adyacentes, pero, teniendo en cuenta los frecuentes ataques de algunas tribus indígenas y la inexistencia de una muralla defensiva de piedra al estilo de las medievales europeas, da la impresión de haberse buscado con ese cinturón fluvial una especie de frontera natural de protección, o al menos un primer obstáculo o elemento de seguridad.

El plano firmado por Juan Crouset en 1798 es uno de los más ilustrativos para el presente estudio. Centrándonos en el arroyo de Santa Lucía, se encuentran identificados -de poniente a oriente- diversos lugares. Primeramente se advierte que el "ojo de agua de Santa Lucía", coincidente con el sitio que ocupa actualmente el Obelisco, y el “ojo de agua del Roble”, próximo al emplazamiento en que hoy se encuentra la basílica del mismo nombre, generan un caudal de agua que fluye hacia la "presa de Nuestra Señora de Guadalupe", también conocida como "presa chiquita". En el plano se representa el agua represada; la cortina de la presa, sobre la calle Escobedo, se convertiría en un puente. De la presa salen dos ramales o

\footnotetext{
${ }^{21}$ Martínez, Óscar E.; “Monterrey, ciudad nueva, ciudad vieja”; en Cavazos, Israel (coord.); La enciclopedia de Monterrey; Grijalbo / El Diario de Monterrey; Monterrey; 1996; t. 2; p. 18.

${ }^{22}$ Moreno, Rebeca y Contreras, Camilo; "La ciudad del conocimiento: entre slogans y realidades"; en Palacios, Lylia (ed.); Cuando México enfrenta la globalización. Permanencias y cambios en el área metropolitana de Monterrey; Universidad Autónoma de Nuevo León; Monterrey; $2010 ;$ pp. 7.
}

152

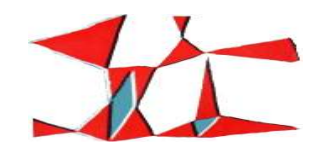

Anuario № 25, Escuela de Historia

Revista Digital № 4, Facultad de Humanidades y Artes, Universidad Nacional de Rosario, 2013 ISSN 1853-8835 
acequias: la que discurre más al norte, identificada como "acequia para otras labores", daría servicio a diversas actividades agropecuarias por el rumbo nororiental del ejido; la acequia sur confluye poco después con la proveniente del "ojo de agua de la ciudad" -en la que moría la calle Allende- hasta ver sus aguas represadas de nuevo, en este caso por la "presa de la Purísima Concepción", coincidente con el actual puente de la Purísima, sobre la calle Diego de Montemayor. Lo interesante de este segundo represe es que en sus márgenes se forma una arboleda de sabinos seculares, conocida como la Alameda ${ }^{23}$, que funcionó por tanto como paseo, pudiendo verse en ella el antecedente más antiguo del actual Paseo Santa Lucía. El espacio ocupado por la Alameda, dispuesta longitudinalmente en sentido poniente-oriente, corresponde hoy aproximadamente al sector comprendido entre las calles 5 de Mayo, 15 de Mayo, Zuazua y Diego de Montemayor, es decir, a la zona del Museo de Historia Mexicana. Por otra parte, de la cortina de la presa de la Purísima salen otras dos acequias: una se dirige al norte, a la hacienda de Labores Nuevas -que tuvo su cabecera por la actual colonia Madero-, y la otra, la "acequia del Pueblo de los Indios", se abre paso al oriente, hacia Guadalupe. El Paseo Santa Lucía deriva precisamente del trazado de esta última.

En el plano de Isidoro Epstein, de 1865, ya no está la "presa chiquita" sobre Escobedo, y se aprecia el "ojo de agua de la ciudad" muy crecido, formando casi una laguna. Se representa de nuevo la zona de inundación, así como el puente de la Purísima y la represa, de la que siguen saliendo las dos acequias. Es interesante comprobar cómo la actual calle Vicente Rivapalacio, entonces calle de las Tenerías, se forma a partir de la acequia de Labores Nuevas, siguiendo su curso. Y la aquí llamada "acequia para Guadalupe" condiciona también el trazado de la calle Rincón del Diablo, hoy Jesús González Ortega, en cuyo extremo oriental -lado norte- se representa el Molino de Hércules. El plano revela igualmente que la acequia de Guadalupe cruzaba el río Santa Catarina, ya fuera por encima, a través de un puente de madera, o por debajo, mediante un sifón o pequeño túnel.

Razones de salubridad e higiene, esgrimidas sobre todo por el doctor José Eleuterio González, Gonzalitos, llevaron a canalizar el cauce natural del arroyo Santa Lucía a partir de la década de 1860. Surgió así lo que se conoció popularmente como "el Canalón", cuya construcción se reforzó en determinados sectores mediante potentes paredes o taludes; algunas partes se cerraron con bóvedas, mientras que otras

\footnotetext{
${ }^{23}$ Más tarde, a partir de 1861, cuando empieza a trazarse lo que hoy conocemos como Alameda Mariano Escobedo, aquella pasó a ser la "Alameda vieja". Agradezco a Juan Manuel Casas el haberme proporcionado este y otros datos históricos.

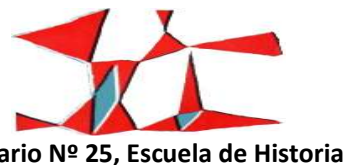


quedaron abiertas. Diversas fotografías antiguas muestran algunos de los usos que le dio la población, lavado de ropa y baño o aseo personal principalmente, sin ser incompatible este último con el divertimento, el juego y la distracción. Bajo el actual canal artificial del Paseo Santa Lucía está la tubería del canalón original. El Paseo vino a sustituir a la calle Domingo Gayosso, que a su vez reemplazó en su día a la acequia del Pueblo de Indios o de Guadalupe. Antes de convertirse en la calle Gayosso, la acequia se cubrió con placas de concreto armado, bien visibles todavía a principios de este siglo desde Platón Sánchez hacia el oriente; al poniente, la calle disponía de pavimento normal. De acuerdo al testimonio oral del arquitecto y erudito local Juan Manuel Casas, las juntas de unión de esas placas presentaban a veces ciertas ranuras a través de las cuales podía verse y oírse el fluir del agua.

Las fuentes de archivo ofrecen interesantes testimonios sobre los usos recreativos que se le fueron dando al canalón desde finales del siglo XIX. En el Archivo Histórico de Nuevo León se conserva un valioso expediente sobre el particular. ${ }^{24}$ De acuerdo a esa documentación, la primera iniciativa data de 1888 , cuando el Ayuntamiento de Monterrey dio un visto bueno unánime a la solicitud presentada por José María Elizondo para "construir dos o más lanchas con el fin de establecer un paseo en el agua que corre desde el punto denominado Ojo de Agua, por el canal, hasta la calle Dr. Coss". Elizondo, al que las fuentes identifican a veces como el "empresario del Paseo del Ojo de Agua", pidió también licencia ese mismo año para establecer unos baños de regadera en el propio Ojo de Agua, siendo igualmente aprobada la petición. Todo indica que fue la primera vez que se autorizó la explotación de un bien público como el agua del ojo de la ciudad a particulares. Más allá del beneficio económico, en ello habría influido la urgencia de fomentar la higiene y la salud de la población -verdadera obsesión de la época-, y en menor medida las consideraciones en favor del recreo y la distracción. Téngase en cuenta que la ciudad de entonces no contaba todavía con servicios de agua potable y drenaje.

La licencia otorgada a Elizondo fue por cinco años, y no parece haber tenido renovación. Sabemos por Moreno ${ }^{25}$ que en 1894 se otorgó una concesión a J. Daniel Nations para establecer un lugar de baños o balneario en el mismo sitio, pero la empresa no prosperó. Sí lo hizo una nueva iniciativa de 1897 debida a

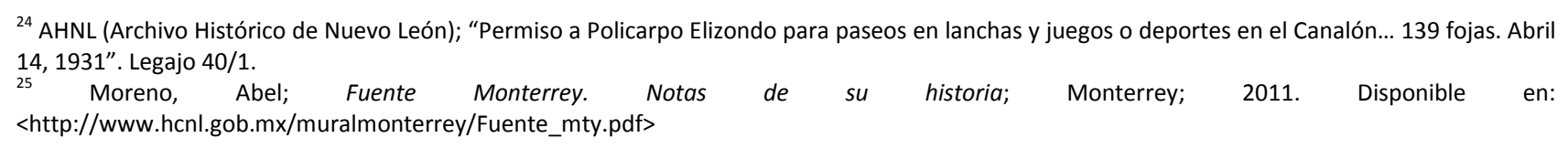
154

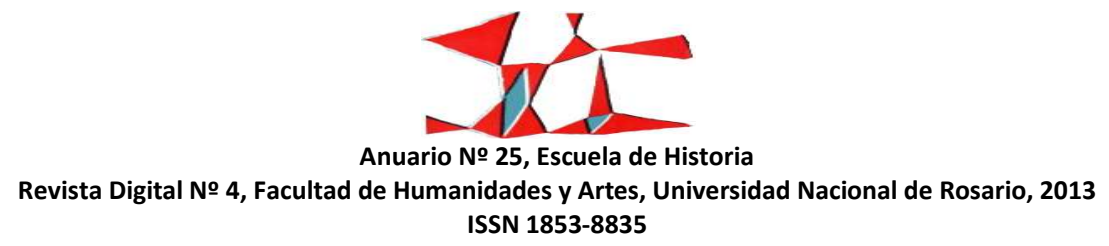


Amado Fernández, que dio lugar a la Compañía de Baños Monterrey, conocida popularmente como "Alberca Monterrey" o simplemente "La Alberca", ubicada en la esquina surponiente del cruce que entonces formaban las calles Zaragoza y Allende. Sirviéndose por entero del ojo de agua de la ciudad, fue un espacio para la recreación, el deporte y la higiene que llegó a obtener del Gobierno Federal la consideración de "utilidad pública". No obstante, después de que en 1950 una investigación histórica del arquitecto Joaquín A. Mora ubicase en ese preciso lugar el sitio original de la fundación de Monterrey, empezó a pedirse el rescate de ese espacio para la ciudad. Expropiadas y demolidas en 1961, las instalaciones de La Alberca dieron paso dos años después al Parque Monumento a los Fundadores de Monterrey, más conocido como Fuente Monterrey, espacio de recreo que fue remodelado en los años 80 en el contexto de las obras de la Macroplaza.

Pero el antecedente más notable del Paseo Santa Lucía es probablemente el relacionado con el permiso concedido en 1931 a Policarpo Elizondo -¿pariente de José María?- para ofrecer al público "paseos en lanchas y juegos o deportes acuáticos" en el canalón, concretamente en el tramo comprendido entre la desembocadura de La Alberca y las compuertas que existían a la altura de la calle Diego de Montemayor. El expediente relativo a la concesión revela la intención de denominar "Parque Luna" a la atracción, pretendiendo tal vez evocar el neoyorkino Luna Park, una de las instalaciones del famoso parque de diversiones urbano de Coney Island, que tuvo precisamente su mejor momento en las primeras décadas del siglo XX. ${ }^{26}$ Como allí, aunque a una escala mucho más modesta, el objetivo de Policarpo parece haber sido hacer negocio produciendo recreo y placer a los ciudadanos. Para ello consideraba preciso "salir del uso común de espectáculos y diversiones establecidos hasta hoy en la ciudad", es decir, ofrecer algo nuevo. Y no pasa por alto la apuesta estética que su propuesta conlleva, pues, "quitándole [al canalón] el repugnante aspecto que presenta, contribuiré en ese lugar al embellecimiento de la ciudad". Sin embargo, el negocio de Policarpo no duró mucho; al fracaso económico se sumó el acoso de las comunidades agrícolas de las haciendas de Labores Nuevas y de la Villa de Guadalupe, contrariadas por la disminución del agua que les llegaba para regar sus siembras.

\footnotetext{
${ }^{26} \mathrm{AHNL}$; leg. 40/1.
}

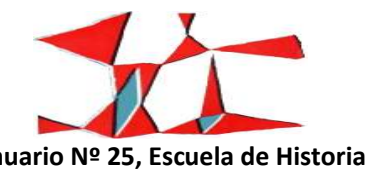




\section{La condición posmoderna del Paseo Santa Lucía}

En su estudio sobre la ciudad posmoderna, Amendola considera claves dos aspectos: la "magia" y el "miedo". ${ }^{27}$ El subtítulo del libro reza precisamente "Magia y Miedo de la Metrópolis Contemporánea". La magia remite a lo espectacular, y el espectáculo se sustenta básicamente en la imagen -a menudo aparatosa u ostentosa-, que a su vez se ofrece a la vista para diversión, deleite o asombro de los espectadores, en este caso ciudadanos y turistas. La magia busca el engaño de los sentidos, la consecución de efectos sobrenaturales o contrarios a las leyes naturales. No es casualidad que el sentir posmoderno esté emparentado con la cultura teatral del barroco -el mundo de las apariencias-y con el gusto romántico por la evasión de una realidad que resulta casi siempre desagradable; esa evasión, en el espacio y/o en el tiempo, demanda grandes dosis de fantasía. Aplicada a la ciudad, la magia es capaz de producir encanto, hechizo y atractivo. Y esto, resultar atractivas, es precisamente lo que persiguen hoy muchas ciudades del mundo, Monterrey entre ellas, con la intención de posicionarse globalmente. Estar en condiciones de competir en el mercado global de ciudades exige dotarse de una imagen urbana susceptible de atraer turismo e inversiones de capital.

Benjamin creía que lo político se juega en escenarios -como el de la estética y las imágenesaparentemente ajenos al de la política propiamente dicha. El desaforado énfasis de nuestra época en la imagen ha conducido a la "sociedad del espectáculo", idea debordiana que tiene su precedente más directo precisamente en Benjamin. ${ }^{28}$ Para Guy Debord, ${ }^{29}$ alma y cabeza del situacionismo, el espectáculo no es un conjunto de imágenes, sino una relación social entre las personas mediatizada por las imágenes.

Lo mágico-espectacular está bien representado en Monterrey por el Paseo Santa Lucía, aunque no es este el único ejemplo. Los dos espacios conectados por el Paseo, la Macroplaza y el Parque Fundidora, participan también de ese espíritu. Se ha dicho del gobernador Alfonso Martínez Domínguez (1979-1985), gran promotor de la Macroplaza, que impulsó un gobierno "con obras y acciones espectaculares, como correspondía a un político de altos vuelos". La estética urbana no asumía tanta relevancia desde la época de Bernardo Reyes (1885-1909). En su primer mensaje ya como gobernador, Martínez Domínguez señaló que

\footnotetext{
${ }^{27}$ Amendola, Giandomenico; La ciudad posmoderna...; Ob. Cit.

${ }^{28}$ Benjamin, Walter; La obra de arte en la época de su reproductibilidad técnica; Ítaca; México D.F.; 2003 (1936).

${ }^{29}$ Debord, Guy; La sociedad del espectáculo; Pre-Textos; Valencia; 2008 (1967).
}

156

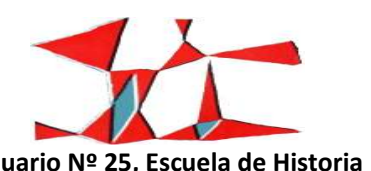


Monterrey era "una ciudad fea, sucia y chaparra, y que era necesario aplicarle un gran esfuerzo de regeneración urbana". ${ }^{30}$ Del Parque Fundidora bastará con aludir a la principal atracción que ofrece a sus visitantes el Museo del Acero, inaugurado en 2007 y ubicado en el alto horno número 3 de la antigua Fundidora: se la conoce como "el show del horno", elocuente expresión que hace referencia al espectacular simulacro multimedia de los procesos técnicos que tenían lugar allí.

Con otros de los denominados "macroproyectos" urbanos sucedería lo mismo. El Barrio Antiguo, producto de una supuesta rehabilitación del centro histórico de la ciudad implementada a partir de finales de la década de 1980, responde a una intervención típicamente posmoderna. Frente al criterio radical del futurista Marinetti, que había instado en 1909 -en nombre de la modernidad- a "destruir sin piedad las ciudades veneradas", aquí trató de revalorizarse un barrio tradicional con miras al desarrollo de industrias turísticas y culturales, del ocio y el entretenimiento. Las cuestiones estéticas pasaron nuevamente a primer plano. De ahí la ocultación -por soterramiento- de postes, cables y otros atributos modernos, indeseables en este nuevo contexto cultural. Al final, la rehabilitación fue más un "proceso parcial y fragmentario de simple renovación físico-espacial, con carácter de intervención cosmética y escenográfica", que una verdadera regeneración integral capaz de vivificar el tejido social y urbano de la zona. ${ }^{31}$ Además, el lamentable manejo de las cuestiones relativas al ambiente arquitectónico ha hecho que el viejo barrio pierda autenticidad en la misma medida que gana falsedad, llegándose a una "caricaturización del patrimonio cultural de 20 manzanas". Estamos ante el triunfo de la apariencia. Dignas fachadas de raigambre vernacular y colonial no se corresponden con los nuevos usos que se dan cita tras ellas; así se aprecia en una película ambientada en Monterrey, 7 días, en la que una hermosa casona del barrio alberga actividades ilícitas.

Inaugurado en 2003, el Puente o Viaducto de la Unidad, conocido popularmente como Puente Atirantado, es un claro ejemplo de cómo, en virtud de las nuevas exigencias de imagen urbana, la utilidad práctica es ampliamente rebasada por el espectáculo, en este caso ingenieril. El Puente y el Paseo Santa Lucía son producto de gobiernos de distinto signo político, PAN y PRI respectivamente; este último partido

30 Moreno, Abel; Fuente Monterrey. Notas de su historia; Monterrey; 2011; p. $28 . \quad$ Disponible en: <http://www.hcnl.gob.mx/muralmonterrey/Fuente_mty.pdf>

${ }^{31}$ Salgado, Antonio; “El Barrio Antiguo de Monterrey: ¿Tradición a pesar de todo, o transformación a cualquier precio?”; en Contreras, Camilo y Narváez, Adolfo B. (coords.); La experiencia de la ciudad y el trabajo como espacios de vida; El Colegio de la Frontera Norte / Plaza y Valdés; Tijuana; 2006; p. 161.

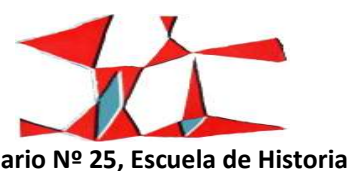


ha llegado a utilizar el Puente en campaña electoral como arma arrojadiza contra los panistas, basándose en la presunta desproporción entre medios y fines y en la falta de trascendencia social del viaducto. Pero lo cierto es que el Paseo, sin perjuicio de los beneficios sociales que -al igual que el Puente- haya podido traer aparejados, responde a lo mismo: la obsesión de los gobernantes por la imagen y el espectáculo. No debe olvidarse que aunque la idea de Santa Lucía es anterior a la celebración del máximo evento internacional organizado por la ciudad en toda su historia, el Fórum Universal de las Culturas Monterrey 2007, al final acabó ligándose a él, pues la concesión de la sede como franquicia de la patente barcelonesa implicaba el desarrollo de un proyecto de regeneración urbana.

En cuanto al "miedo", podría aludirse a la creciente proliferación de fraccionamientos residenciales privados, que fomentan la segregación socioespacial, o a lo ocurrido hace un par de años (2011) en una serie de calles que dan servicio a casas-habitación de la colonia Anáhuac, en el municipio metropolitano de San Nicolás de los Garza. Esas calles -espacios públicos, no lo olvidemos- han sido cerradas por las autoridades a través de vallas metálicas fijas que impiden el paso tanto de vehículos como de peatones. Se conculca así uno de los principios básicos de la calle moderna, el de favorecer en todo momento la fluidez de tránsito, especialmente el rodado. La presencia de esas vallas no garantiza la seguridad, puesto que otras calles vecinas siguen abiertas, pero constituye un alivio psicológico. En efecto, con ello se pretende mitigar el temor y la angustia generados por la inusitada ola de violencia e inseguridad asociada al fenómeno del narcotráfico y del crimen organizado, que azota la metrópoli desde 2009. Pero la sensación de miedo e inseguridad ya se había instalado en la sociedad regiomontana, como en otras sociedades posmodernas, mucho antes de 2009. Porque el miedo es alimentado por la propia diversidad y complejidad de esas sociedades. Bauman se ha servido del término "mixofobia" para designar la reacción de buena parte de la ciudadanía ante la perturbadora variedad de tipos y estilos de vida que coexisten en las calles de las ciudades contemporáneas. ${ }^{32}$ De ahí que el miedo se haya dejado sentir también en el propio Paseo Santa Lucía, inaugurado en 2007, como atestigua la instalación de torretas de vigilancia y cámaras de seguridad, y la continua presencia de agentes de policía a bordo de lanchas ad hoc o de los nuevos y futuristas segway PT. Sin embargo, y a pesar de que esas torretas son de alta tecnología, supuestamente blindada, con cámaras de visión diurna y nocturna, sistemas de sonido para monitoreo constante y un centro de

\footnotetext{
${ }^{32}$ Bauman, Zygmunt; Amor líquido. Acerca de la fragilidad de los vínculos humanos; Fondo de Cultura Económica de Argentina; Buenos Aires; 2005; p. 145.
}

158

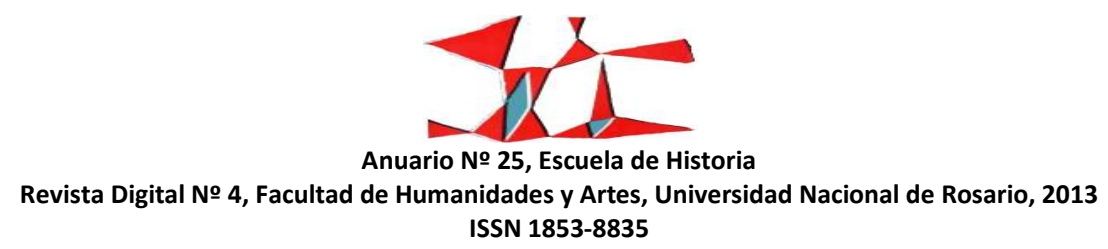


comunicación integrado..., la eficacia de estas medidas es cuestionable: el 8 de septiembre de 2010 un hombre fue secuestrado a golpes frente a una de esas torres de la policía estatal. ${ }^{33}$ Las cámaras, además, producen en muchas personas la desagradable sensación de estar siempre bajo control.

La excepcionalidad del Paseo en la ciudad se expresa también en términos de diseño. La sujeción al trazado sinuoso de la antigua acequia de Indios y del viejo canalón determina su carácter orgánico, que contrasta con la geometría rectilínea de la mayor parte de las calles de la ciudad. Frente al damero imaginado ya por el obispo Llanos y Valdés -en un contexto racionalista e ilustrado- a finales del siglo XVIII, que tuvo pleno respaldo en el seno de la urbe moderna, el gusto posmoderno se identificó más con los postulados de Camilo Sitte, cuya crítica a la monotonía de los trazados reticulares cobró fuerza a través de su libro Construcción de ciudades según principios artísticos, publicado en 1889. Afirmando la "preeminencia estética" de la irregularidad, Sitte proponía recuperar el valor artístico de los contrastes visuales de las ciudades antiguas y de sus calles sinuosas, sensibles al relieve, y renunciar a los espacios excesivos. Defendía una concepción "cualitativa" de lo urbano, basada en el rescate de los valores pintorescos y ambientales de la ciudad tradicional. En ese contexto fue clave también el jardín paisajista, conocido también como jardín romántico o inglés, que ejerce una indudable influencia en el diseño del Paseo Santa Lucía.

Un diseño verdaderamente posmoderno era incompatible con elementos preexistentes de clara resonancia iconográfica moderna. De ahí que fuera necesario intervenir en la subestación eléctrica que se encuentra a la altura de la avenida Félix U. Gómez, ocultándola mediante una pared que después se decoró con murales diseñados por el artista Gerardo Cantú (Imagen 3). La dureza industrial de la subestación, emblemática en otro tiempo, ${ }^{34}$ casaba mal ahora con la delicadeza de las fantasías acuáticas, los jardines, las flores y las piezas artísticas. En relación a estas últimas, hay que añadir a las citadas obras de Cantú otros cinco murales de Guillermo Ceniceros sobre el andador sur del canal, entre los puentes de Mina y Platón Sánchez, así como la monumental escultura de La lagartera, del oaxaqueño Francisco Toledo, ubicada en el punto inicial del Paseo, y la no menos monumental Serpiente del Eco, versión de la conocida escultura que

\footnotetext{
33 "Secuestran a un hombre en Santa Lucía"; en El Norte; Monterrey; jueves 9 de septiembre de 2010; p. 5.

${ }^{34}$ Prieto, José Manuel; "Monterrey como Estridentópolis: vigencia del ideal urbano de la vanguardia histórica mexicana”; en PALAPA; v. IV; N 1; enero-junio de 2009; pp. 17-31; <http://redalyc.uaemex.mx/src/inicio/ArtPdfRed.jsp?iCve=94814777004>
}

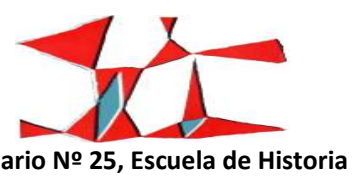


incluyó Mathias Goeritz en el patio de su Museo de El Eco (Ciudad de México, 1953), casi al final del recorrido, junto al Parque Fundidora.

Las obras de arte cualifican la imagen del Paseo, contribuyen a su espectacularidad. No falta en ellas magia y fantasía, cualidades que se expresan también a través de: 1) la propia condición navegable del canal artificial; 2) diversos modelos de lanchas, desde el convencional hasta el de tipo góndola veneciana, pasando por la trajinera de Xochimilco; 3) un pintoresco puente circular; 4) vestigios históricos que nos hablan de tiempos pasados, como un potente muro de sillar del antiguo Molino de Hércules, o incluso piezas de arqueología industrial rescatadas de la antigua Fundidora y desperdigadas por distintos puntos de la parte final del recorrido: en su extremo, una enorme y vieja olla de arrabio se ha convertido, como por arte de magia, en una fuente monumental que vierte agua al canal; 5) carteles informativos con reseñas de acontecimientos históricos y legendarios que permiten evadirse en el tiempo, recrear idealmente el pasado y hacer volar la imaginación, o, para quien no quiera leer y prefiera escuchar un cuento, ahí está la narración, a menudo fantaseada, de los conductores-guías de las lanchas; 6) fuentes, cascadas -falsas cascadas de cemento simulando roca natural-, surtidores y juegos de agua que alcanzan su cénit en la atracción o divertimento conocido como "Fuente de Olas", localizada en la parte más ancha del canal, donde parece formarse una pequeña laguna: gracias a un mecanismo motorizado es posible generar la ilusión de un mar embravecido. Todo esto era lo que no ofrecía el Parque Lineal del río Santa Catarina, inaugurado igualmente en 2007 y destruido por el huracán "Alex" en 2010. Probablemente por eso tuvo siempre muchos menos usuarios que Santa Lucía. Ambos fueron pensados como espacios públicos de recreo y esparcimiento, pero el Parque Lineal se concibió en clave más funcional y sobria. A este se iba a caminar, a hacer ejercicio; Santa Lucía ofrece mucho más que eso.

A través del cinturón montañoso, bien visible desde el Paseo, la naturaleza coopera también a ese objetivo de lo fantástico-espectacular, como atestigua la mágica silla de montar del famoso cerro homónimo. La arquitectura no se queda atrás: edificios de vanguardia como el Museo de Historia Mexicana, el Museo del Noreste y la elevada Torre de Gobierno, que ligan pasado y presente, complementan el espectáculo; sólo el estacionamiento en superficie anejo a la Torre, cercano en su carácter moderno a la subestación eléctrica, escapa a ese objetivo. Pero no son solo referencias visuales; es el ambiente en su conjunto, al que también contribuye el sonido envolvente del agua. Todo ello genera la ilusión de un mundo 160

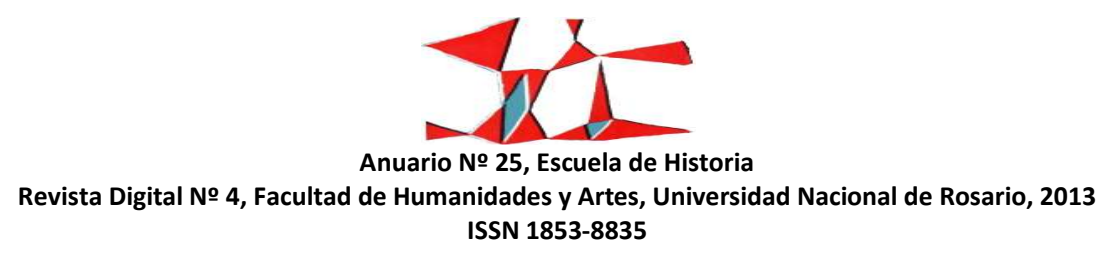


de maravillas, apacible y encantado, que hace olvidar por unos momentos -mientras se recorre el Paseo- la fealdad y aspereza de la "ciudad real". La razón primordial del diseño es estética; en su nombre se sacrifica la funcionalidad que habría podido ofrecer, por ejemplo, un barandal de seguridad o protección en el límite de los andadores con el canal, sobre todo en la zona donde aquellos son más estrechos. Lo que sea con tal de conseguir efectos estéticos capaces de emocionar y producir placer, un placer más sensorial que racional.

Detrás de la idea y el diseño del Paseo Santa Lucía está, indudablemente, el Riverwalk de San Antonio (Texas). Baste decir que Sócrates Rizzo, primer político en impulsar el proyecto de Santa Lucía primero como alcalde de Monterrey (1889-91) y luego como gobernador de Nuevo León (1991-95)-, tuvo como asesor destacado a Alvin Groves, responsable de parte del canal de San Antonio. ${ }^{35}$ A menudo se olvida otro referente, tal vez no tan directo pero igualmente notable: Venecia, la ciudad de los canales. Una ciudad asociada al romanticismo, la fantasía y el ensueño, términos en los que forma parte del imaginario urbano mundial a través del cine, la televisión, la literatura, el arte, la publicidad, etc. Ya me he referido a las góndolas que surcan ocasionalmente las aguas de este canal, pero también podría aludirse a algún puente de estilo veneciano (Imagen 4) e incluso echar mano del cine una vez más: de 2001, año en que solo existía el primer tramo de Santa Lucía, data una película de Ángel Mario Huerta ambientada en Monterrey, Inspiración, que incluye una escena en la que una góndola pasa bajo el puente de la Purísima y lleva a una joven pareja hasta el atracadero de un ficticio restaurante ubicado en el lugar que ocupa el llamado "Foro Paseo Santa Lucía", muy cerca de la calle Javier Mina (Imagen 5). No diré que la escena parece rodada en Venecia, pero sí que evoca automáticamente esa ciudad. No falta en internet quien identifica el lugar de la película con Xcaret, famoso parque temático de la Riviera Maya, del mismo modo que el motivo de los canales venecianos ha sido recreado en centros comerciales de Cancún. Nada nuevo por otra parte. Koolhaas nos recuerda el papel que jugó la atracción conocida como "Los Canales de Venecia" en el conjunto del Dreamland (País de los sueños, 1904-11), uno de los principales espacios-espectáculo que tuvo el parque de diversiones de Coney Island, en Brooklyn (Nueva York). A partir de su dominio de la "tecnología

\footnotetext{
${ }^{35}$ Díaz, Felipe (dir.); El Paseo de la Historia; Gobierno del Estado de Nuevo León; Monterrey; 2007; pp. 195-196.
}

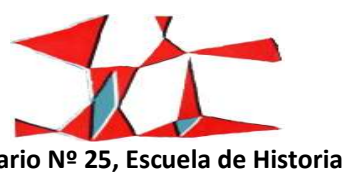


de lo fantástico", ${ }^{36}$ Coney Island en general y Dreamland en particular pasan por ser el laboratorio de pruebas en que, según Koolhaas, se gestó el Manhattan posmoderno.

\section{Valoraciones del Paseo: de la crítica académica a la opinión de los usuarios}

Tan legítimo es pregonar con fruición la espectacularidad-grandiosidad del Paseo Santa Lucía y su innegable éxito social o popular, como señalar críticamente los riesgos que conlleva someter la política urbanística a las exigencias del espectáculo. Esto último es, además de un derecho, un deber moral de la comunidad científica y académica, de Universidades e investigadores del campo de las humanidades y las ciencias sociales. Como responsable del proyecto, el gobierno estatal se ha limitado a hacer apología del resultado obtenido, libre de toda crítica (autocrítica). Ha contado para ello con medios y recursos extraordinarios que le han permitido difundir la obra de manera igualmente espectacular; baste citar la implementación de campañas publicitarias de alcance local, nacional e internacional y la publicación de libros de gran formato y calidad visual; ${ }^{37}$ alguna de estas publicaciones ha sido subida a la Red, permitiendo así que su contenido pueda ser consultado desde cualquier parte del mundo. Semejante labor propagandística ha contribuido a generar en la ciudadanía una corriente de opinión muy favorable al Paseo, hasta el punto de su aceptación absolutamente acrítica. Quienes ejercen la crítica arquitectónica y urbanística a nivel profesional saben bien que la presencia deslumbrante de la obra puede llegar a cegar la capacidad crítica, a anular el juicio. Desde la inauguración y a lo largo de estos años de entusiasmo unánime y aprobación generalizada por parte del público, pocos se han preguntado cuál podría ser el futuro del canal, ni el costo de su mantenimiento, ni la veracidad del carácter sustentable que -falazmente- ha llegado a atribuírsele. Desde hace unos años tanto la ciudad como el Paseo enfrentan nuevos retos: por una parte, el espectáculo amable de Santa Lucía ha quedado provisionalmente opacado por otro espectáculo, el de la violencia y el crimen, que reclama incluso más portadas de prensa, obligando a renunciar de momento a los objetivos de marca-ciudad; por otra parte, si las masas se aburren de ver siempre lo mismo, como bien pudieron comprobar los responsables de los espectáculos de Coney Island, la viabilidad de Santa Lucía podría depender de nuevas atracciones y rediseños, entrando así en una espiral sin fin. Ya se sabe: renovarse o morir.

\footnotetext{
${ }^{36}$ Koolhaas, Rem; Delirio de Nueva York; Gustavo Gili; Barcelona; 2004 (1978); p. 55.

${ }^{37}$ Díaz, Felipe (dir.); El Paseo de la Historia; Gobierno del Estado de Nuevo León; Monterrey; 2007. Farías, Carolina; Memoria de una transformación: Santa Lucía, Fundidora, Parque Linea; Fondo Editorial de Nuevo León; Monterrey; 2009 (disponible en <http://issuu.com/24design/docs/memoria>). 162

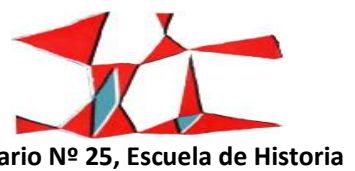


Buena parte de la crítica que puede hacérsele al Paseo Santa Lucía no es exclusiva de esta obra, sino que es compartida por proyectos similares de otras ciudades del mundo cuyos responsables entienden también la imagen y la seducción estética como condición necesaria para una verdadera transformación urbana que permita competir en el mercado global de capitales. Ello ha llevado a Muñoz a hablar de "urBANALización", es decir, a señalar la aparición de un tipo de urbanización banal del territorio, en virtud del cual ciudades diferentes producen paisajes estandarizados y comunes. Leach, por su parte, considera que la hipertrofia estética puede traducirse en una forma de "anestesia" o "narcótico" capaz de alterar la conciencia del sujeto y operar contra todo sentido de compromiso ético y social. ${ }^{38} \mathrm{~A}$ nivel más específico, el Paseo se ha visto como "ilusión", como "burbuja de primer mundo". ${ }^{39}$ Para Montaner, ${ }^{40}$ tuvo la virtud de conectar la Macroplaza con el Parque Fundidora, pero no deja de ser un eje temático "poco relacionado con la parte de ciudad que atraviesa". Frente a la idealista pretensión inicial de ser un espacio de encuentro para todos, sin distinción de clases, se ha convertido en un "lugar al que concurren los habitantes de los sectores populares de la ciudad en busca de recreación dominical” ${ }^{41}$. Y un atento observador de la realidad urbana regiomontana como Fermín Téllez hace crítica a través de sus fotografías, que comparte en un foro de debate arquitectónico y urbanístico en internet (www.skyscrapercity.com); en este sitio pueden verse imágenes de Santa Lucía que revelan el rápido deterioro que han venido sufriendo algunos elementos del Paseo. Personalmente, no cuestiono tanto el qué se ha hecho -el Paseo- cuanto el cómo se han hecho las cosas: ¿por qué no rescatar en la medida de lo posible los vestigios que quedaban? ¿Por qué no recuperar la tubería del antiguo canalón que quedó bajo el actual canal artificial? ¿Por qué no apostar por lo natural frente a lo artificial?

Cedamos ahora la palabra a los usuarios del Paseo, retomando los resultados del sondeo de opinión que mencionaba al principio. Una mayoría de encuestados (47\%) confiesa recorrer el Paseo una vez cada varios meses, lo cual supone una frecuencia de uso relativamente baja, que tal vez se explica en el contexto actual por la situación de inseguridad que vive la ciudad. La opción más común es hacer el paseo en familia (51\%), y en menor medida con amigos. La mayor parte hace el recorrido caminando; solo un $35.5 \%$ admite

\footnotetext{
${ }^{38}$ Leach, Neal; La an-estética de la arquitectura; Gustavo Gili; Barcelona; 2001.

${ }^{39}$ Durán, Jesús A.; “El Paseo Santa Lucía. Una crónica del paisaje por el usuario”; en Contexto (Revista de Arquitectura, UANL); Año 2, N² 2; enero de 2008; p. 21.

${ }^{40}$ Montaner, Josep Maria; “La herencia del Fórum”; en El País (edición de Cataluña); jueves 20 de enero de 2011.

${ }^{41}$ Moreno, Rebeca y Contreras, Camilo; “La ciudad del conocimiento: entre slogans y realidades"; en Palacios, Lylia (ed.); Cuando México enfrenta la globalización. Permanencias y cambios en el área metropolitana de Monterrey; Universidad Autónoma de Nuevo León; Monterrey; $2010 ;$ pp. 146.
}

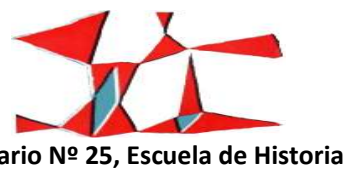


haberlo hecho en lancha alguna vez, y las preferencias no varían sustancialmente en el supuesto de que el servicio de lanchas fuera gratuito. Lo significativo es que la gente llega normalmente al Paseo en camión, en metro y en coche, por este orden; solo un 7\% de los encuestados dice llegar a Santa Lucía caminando, lo que da idea de hasta qué punto no son compatibles la "ciudad real" y el peatón. Por otra parte, estamos ante paseantes poco exigentes: el $78.5 \%$ entiende que el excesivo número de personas en un momento determinado -especialmente en días festivos- no resta calidad a su paseo.

Cuando preguntamos a los usuarios de Santa Lucía si habían paseado alguna vez por el ya desaparecido Parque Lineal del Río Santa Catarina, una abrumadora mayoría (84\%) contestó que no, lo que confirmaría la hipótesis de públicos distintos en función de la oferta de uno y otro espacio públicos. Algo parecido ocurre con las calles adyacentes de Barrio Antiguo: casi un $83 \%$ de los encuestados reconoce no hacer extensivo su paseo por esa zona cuando acude a Santa Lucía. Aunque el objetivo de las autoridades era que las calles contiguas al Paseo se contagiaran del entusiasmo que generó Santa Lucía a nivel de visitantes, no ha sido posible lograrlo, probablemente porque esas vías son comparativamente deficitarias en términos de espectáculo. De ahí que entre las contestaciones de la gente abunden respuestas del tipo "no me gusta", "ya no hay nada [que ver]", "no hay para qué [ir allí]", "no tiene caso [ir allí]" o "no me llama la atención", aunadas a una percepción de mayor inseguridad en la zona. En relación a esto último, el Paseo se percibe más seguro: un $57 \%$ de los encuestados considera "suficiente" la vigilancia y presencia de policías en él; para el $40 \%$ sería "insuficiente", y solo el $1.5 \%$ la considera "excesiva".

Parte de lo dicho en el párrafo anterior confirmaría la relevancia que adquieren los aspectos estéticos, aunque cuando se pregunta a la gente qué valora más del Paseo, la funcionalidad o la estética, son mayoría quienes optan por la primera (48.5\%); casi un $23 \%$ señaló la estética y el $27 \%$ dijo que ambas. Pero lo cierto es que en relación a este asunto tiende a imponerse el equilibrio: al preguntar si se considera necesaria la presencia de barandales de protección en el límite del canal y los andadores, que en cierto modo vendría a ser la misma pregunta de antes pero formulada de otra manera, el sí y el no se reparten a partes iguales. Queda la duda de saber qué han entendido los encuestados por "estética" y "funcionalidad". Preguntados por lo que más les gusta del Paseo, los usuarios se inclinan ampliamente por el agua y todo lo que se relaciona con ella (fuentes, lanchas, etc.); su dimensión estética tiende a imponerse aquí sobre la funcional. En cuanto a lo que menos gusta, las respuestas resultan más variadas, pero son mayoría las que 164

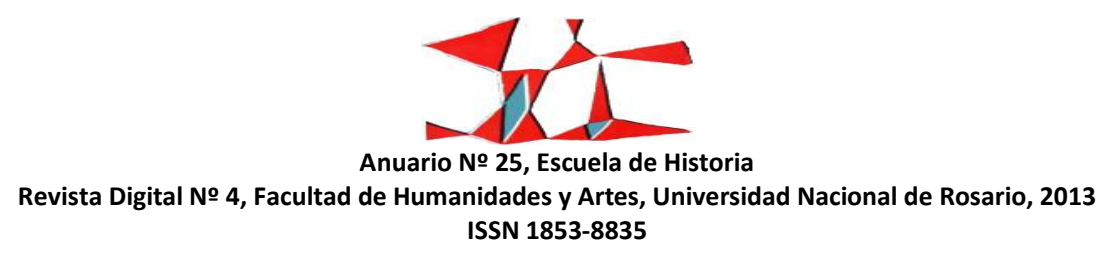


dicen "nada" y las que inciden en la escasez de bancas y sombra. Además, frente a lo que era usual en el antiguo canalón (Imagen 6), un 64\% de encuestados considera que no debe permitirse utilizar las fuentessurtidores-cascadas ni el canal para bañarse, lo cual tiene lógica, entre otras cosas porque en el viejo canalón la corriente mantenía el agua relativamente limpia y oxigenada. Entre las razones esgrimidas por quienes defienden la prohibición destacan las relativas al "mal aspecto" que supondría lo contrario, porque eso "se ve mal", "afea", "quita imagen" y "no sería de primer nivel".

Otra de las cuestiones planteadas consistía en conocer si se estaba o no de acuerdo con la definición del Paseo Santa Lucía como una "burbuja de primer mundo" en la ciudad. Apelando en parte a lo "bonito" del lugar y a su capacidad para atraer turistas, el 58\% dijo suscribir tal aserción. Quisimos saber también si Santa Lucía provocaba en la gente el recuerdo de otros lugares parecidos: al 59\% de los encuestados no le recordaba nada; entre quienes respondieron afirmativamente (31\%), la ciudad texana de San Antonio fue el lugar más evocado. Donde apenas hubo discrepancia fue a la hora de reconocer que el Paseo atrae turistas a la ciudad (87\%). Análoga coincidencia existe (91\%) en cuanto al desconocimiento de lo que se gasta anualmente para mantenerlo en óptimas condiciones.

Lo relativo a los beneficiarios de la obra y al grado de trascendencia social de la misma concita probablemente el mayor interés. Ante la posibilidad de elegir entre ciudadanos, gobierno, comerciantes y opciones mixtas, una mayoría de encuestados (38.5\%) consideró que el Paseo Santa Lucía beneficia principalmente a los ciudadanos. De esto cabe deducir, por tanto, una acertada decisión de gobierno. Sin embargo, a la pregunta de "Si de usted hubiera dependido la decisión, ¿̇habría preferido invertir en el Paseo o en una nueva línea de metro?", la mayoría (58.5\%) se inclina por esta última opción, frente al 36\% que prefiere el Paseo. Y al verse obligados a elegir de nuevo, esta vez entre un macroproyecto como Santa Lucía y paseos más modestos en distintas zonas del área metropolitana, un 71.5\% apoya la segunda opción. Esto tiene bastante sentido en relación al resultado que arroja otra pregunta: la procedencia mayoritaria de los usuarios, en relación al conjunto del área metropolitana, corresponde al municipio de Monterrey (44\%), sin que exista relación proporcional con la población de los demás municipios; ello hace del Paseo un espacio recreativo de carácter municipal más que propiamente metropolitano.

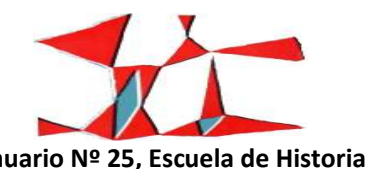




\section{Conclusiones}

En la lógica de la cultura posmoderna las calles han dejado de ser únicamente espacios funcionales de tránsito o simples vías de conexión entre dos puntos de la ciudad. Son mucho más que eso. Son ambientes susceptibles de generar atractivo y seducción estética con fines de beneficio económico, ya sea a través del turismo o de inversiones. Pudiera parecer que esos ambientes -construidos con buenas dosis de magia y fantasía- se destinan solo a viajeros y turistas, pero la población local también los consume. En realidad, lo que consumen unos y otros son imágenes, imágenes superficiales y espectaculares (entretenidas y divertidas) que permiten evadirse por unos instantes de la tediosa realidad, distraerse y olvidar durante unos momentos las miserias urbanas cotidianas. Porque, de acuerdo a esta misma lógica y conforme a una especie de síndrome de Alicia en el país de las maravillas, la realidad se experimenta como algo tremendamente aburrido; de ahí la necesidad de sustituirla a veces por fantasía, por imágenes.

La cultura de la imagen y del espectáculo nos habla de una sociedad y de una filosofía de vida a la que no son ajenas, como ha denunciado Mario Vargas Llosa, ${ }^{42}$ la banalidad, la frivolidad, el facilismo, la superficialidad, el fraude, el embuste y la visión cortoplacista de las cosas, de lo inmediato -eso es justamente el espectáculo-. La "falta de profundidad" impide a menudo discernir la validez de las cosas, discriminar entre lo auténtico y lo postizo. Esta filosofía de vida, que empezó orientando conductas personales, ha acabado afectando de lleno a las ciudades, que no en vano son producto y creación humana. Las imágenes, esas imágenes espectaculares que van construyendo ciudades imaginarias -contrapunto divertido de la aburrida ciudad real-, son las que permiten vender ciudad; nótese que siempre hay mucho interés económico de por medio. La arquitectura suministra muchas de esas imágenes, pero también el urbanismo tiene la facultad de hacerlo a través de proyectos espectaculares como el que nos ocupa. Eso sí, no toda la ciudad puede aspirar a ser imagen: la diferencia con la vecina ciudad real es lo que potencia el valor y el significado de la ciudad de las imágenes. Desoyendo a menudo las demandas que llegan de la ciudad real, necesidades reales y funcionales, el poder político prioriza el desarrollo de macroproyectos (imágenes) que resultan bastante redituables en términos de prestigio e imagen pública, tanto personal como partidista. Al final, la estética termina imponiéndose a las preocupaciones ético-sociales, pues en ella cifran los políticos el instrumento esencial para transformar las ciudades y solucionar sus problemas.

\footnotetext{
${ }^{42}$ Vargas Llosa, Mario; La civilización del espectáculo; Santillana; Madrid; 2012.

166
} 
Los ciudadanos de Monterrey tienen dificultad a la hora de considerar el Paseo Santa Lucía como una calle. ¿Por qué? Porque el imaginario local sigue entendiendo la calle en clave moderna, casi exclusivamente como lugar de tránsito de vehículos - poco o nada apto para el paseo o los desplazamientos a pie-, y porque la excepcionalidad y espectacularidad de Santa Lucía se apartan bastante del carácter prosaico e instrumental de cualquier calle de la ciudad. Pero lo cierto es que ese espacio tiene todos los atributos de una calle, y, de hecho, calle fue (Domingo Gayosso) antes de convertirse en Paseo Santa Lucía.

El posmoderno y mágico Paseo Santa Lucía hace amplio uso de la "tecnología de lo fantástico" (surtidores y juegos de agua, fuente de olas, murales artísticos, edificios de vanguardia, etc.) para resultar seductor y, por extensión, para hacer de Monterrey -junto con otros macroproyectos- una ciudad atractiva de cara al exterior. Cuando algo preexistente se revela incompatible con esta lógica de la seducción y se interpone en el camino, como ocurrió con la moderna subestación eléctrica de la avenida Félix U. Gómez, simplemente se tapa, se oculta, se niega. Lo importante es generar la ilusión de un mundo de maravillas, apacible y encantado, una "burbuja de primer mundo" que hace olvidar por unos momentos la fealdad y aspereza de la ciudad real. De ahí que en el diseño se antepongan las consideraciones estéticas a las funcionales, porque en la estética se cifra la capacidad de emocionar y producir placer sensorial, que es lo que realmente interesa. $Y$ eso es algo que han aprendido muy bien los políticos actuales, cuya imagen pública depende mucho también de la estética. En una ciudad de tradición industrial y aspecto duro como Monterrey nunca se prestó demasiada atención a las cuestiones estéticas. Solo gobernantes que dejaron honda huella en la ciudad y que cultivaron mucho su propia imagen pública, como Bernardo Reyes y Alfonso Martínez Domínguez, se preocuparon por la estética urbana.

Pero en el diseño de Santa Lucía parece haber sido más importante evocar el Riverwalk de San Antonio (Texas), o incluso los canales de Venecia -emblema mundial de ensueño y fantasía-, que tratar de ser ya no digo fieles a la historia local pero sí más cómplices o condescendientes con ella. Para algunos ha sido más fácil encontrar conexiones con Xcaret que con el viejo canalón decimonónico o con los fundacionales ojos de agua. Lo que un día fue una corriente de agua, con todo lo que ello implica, ha devenido kilométrica alberca. La vieja y desaparecida alameda, formidable arboleda de sabinos seculares, haría hoy las delicias de algunos paseantes que denuncian la escasez de bancas y de sombra. En fin, ¿era forzosamente necesario ocultar la tubería del canalón original bajo el actual canal artificial? ¿Por qué no

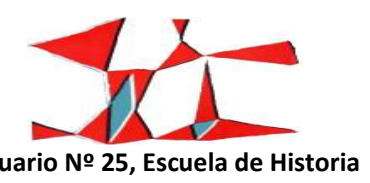


entroncar de modo más natural con los usos recreativos que ya tuvo el antiguo canalón? Aunque se le ha reconocido al Paseo Santa Lucía la virtud de haber conectado la Macroplaza con el Parque Fundidora, no deja de cuestionarse su poca relación con la zona urbana que atraviesa. En cierto modo ese espacio ha perdido autenticidad. La historia parece que se utiliza aquí como coartada.

El éxito social y popular de Santa Lucía es incuestionable, pero desde el ámbito académico e investigador no podemos permitir que la presencia deslumbrante de la obra anule nuestra capacidad crítica. Sobre todo porque es necesario advertir contra los riesgos que implica acomodar las políticas urbanas a las exigencias del espectáculo. Dotado de un extraordinario potencial propagandístico -que consiguió generar en la ciudadanía una corriente de opinión muy favorable al Paseo-, el poder se ha limitado a ensalzar su obra sin el más mínimo asomo de autocrítica. Sería absurdo negar que una obra como esta tiene aspectos positivos, y no pretendo minusvalorarlos, pero a ellos nunca les faltarán voceros. En cambio, la crítica -por más razonada que sea- sale a la superficie o llega a la gente con mayor dificultad. El entusiasmo unánime y la aprobación generalizada de estos años han hecho que no tenga sentido preguntarse por el futuro del canal, ni por el costo de su mantenimiento, ni por la veracidad de la supuesta sustentabilidad de la obra, ni por el previsible aburrimiento en caso de no implementarse nuevas atracciones y rediseños, ni por el rápido deterioro que han venido sufriendo algunos elementos del conjunto, etc. Se quiso que el Paseo fuera un lugar de encuentro para todos, sin distinción de clases, pero la realidad indica que a él concurren básicamente los habitantes de los sectores populares de la ciudad, casi siempre en busca de recreación dominical. Se quiso que Santa Lucía recondujese visitantes a las calles de Barrio Antiguo, pero pocos han hecho extensivo su paseo por esa zona, probablemente porque no ofrece lo mismo en términos de espectáculo. De momento, la aparición de otro espectáculo, el de la violencia y el crimen, ha opacado el atractivo que obras como esta reportaban a la ciudad, y ha puesto sobre la mesa la urgente necesidad de establecer prioridades en la agenda de las políticas públicas.

\section{8}

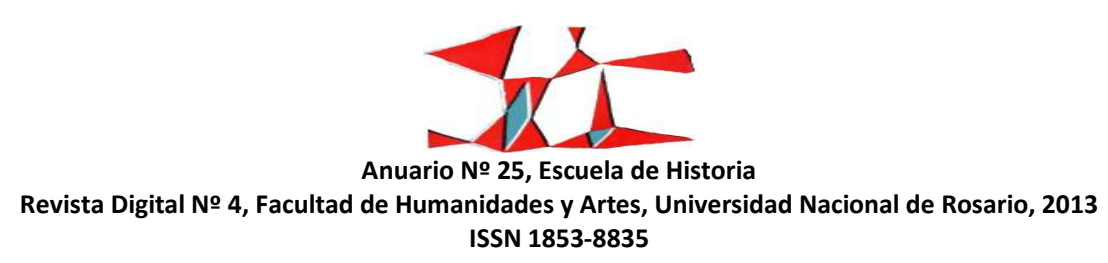


Imagen 1

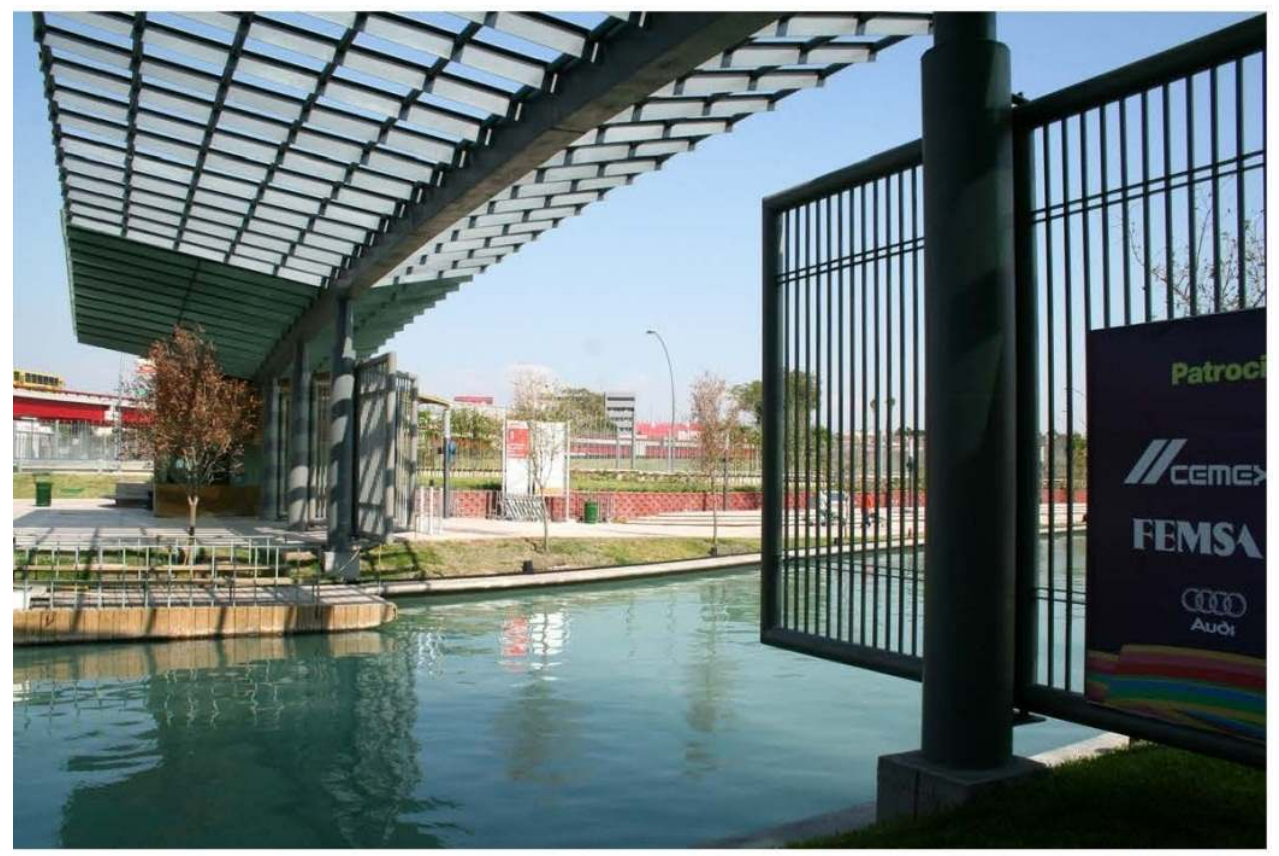

Límite entre las zonas pública y semipública del Paseo, en las proximidades de la Av. Félix U. Gómez. Foto: Ricardo Lazcano (R. L.).

Imagen 2

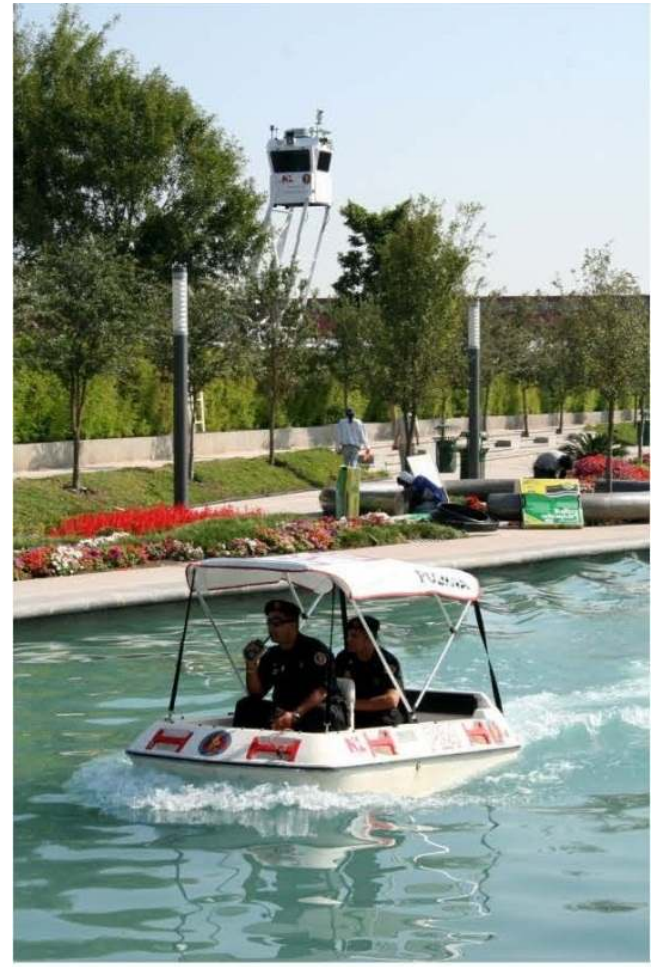

La seguridad en el Paseo Santa Lucía: lancha policial y torreta de vigilancia. Foto: R. L.

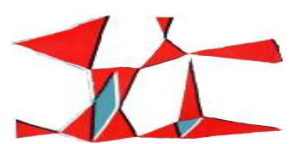

Anuario № 25, Escuela de Historia

Revista Digital № 4, Facultad de Humanidades y Artes, Universidad Nacional de Rosario, 2013 ISSN 1853-8835 
Imagen 3

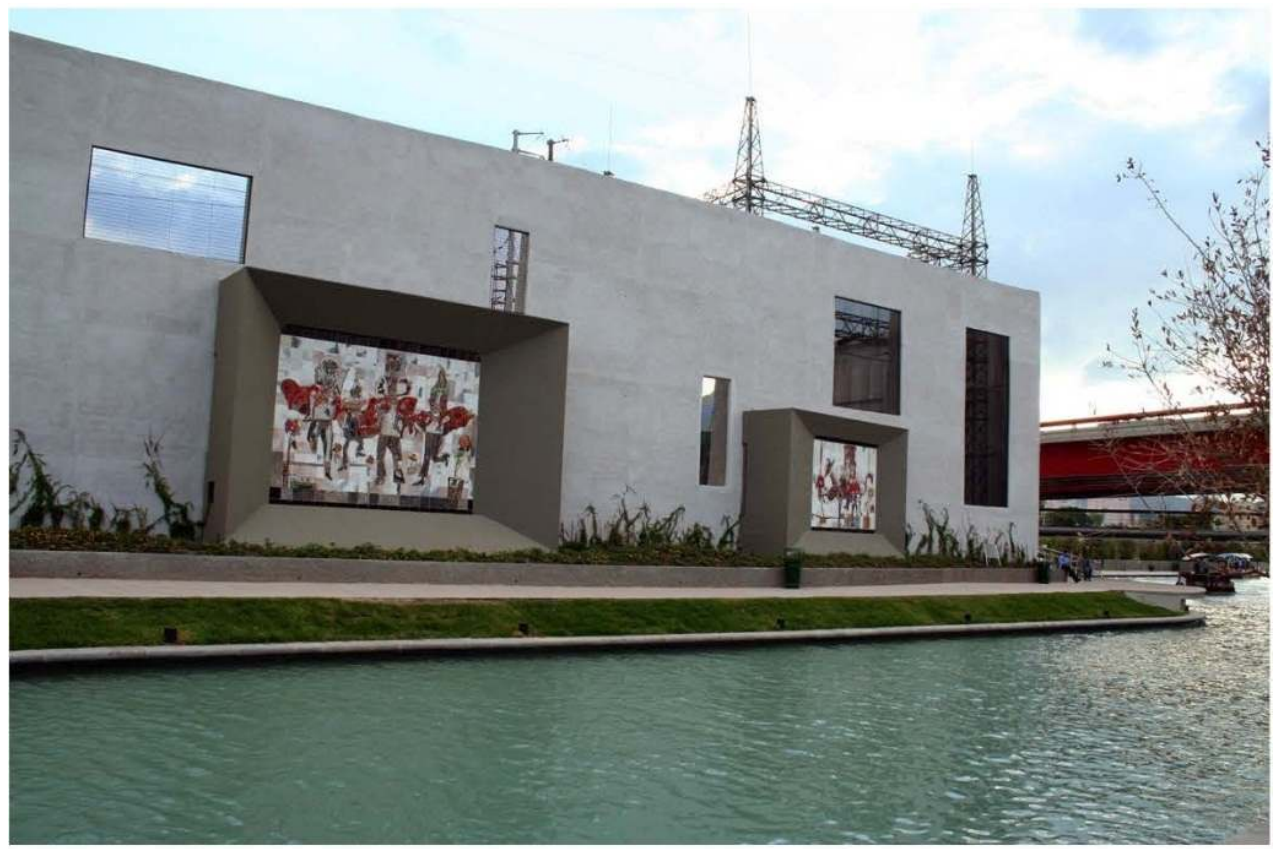

Contra la iconografía moderna. Ocultación de la subestación eléctrica mediante un muro decorado con murales del artista Gerardo Cantú. Foto: R. L.

Imagen 4

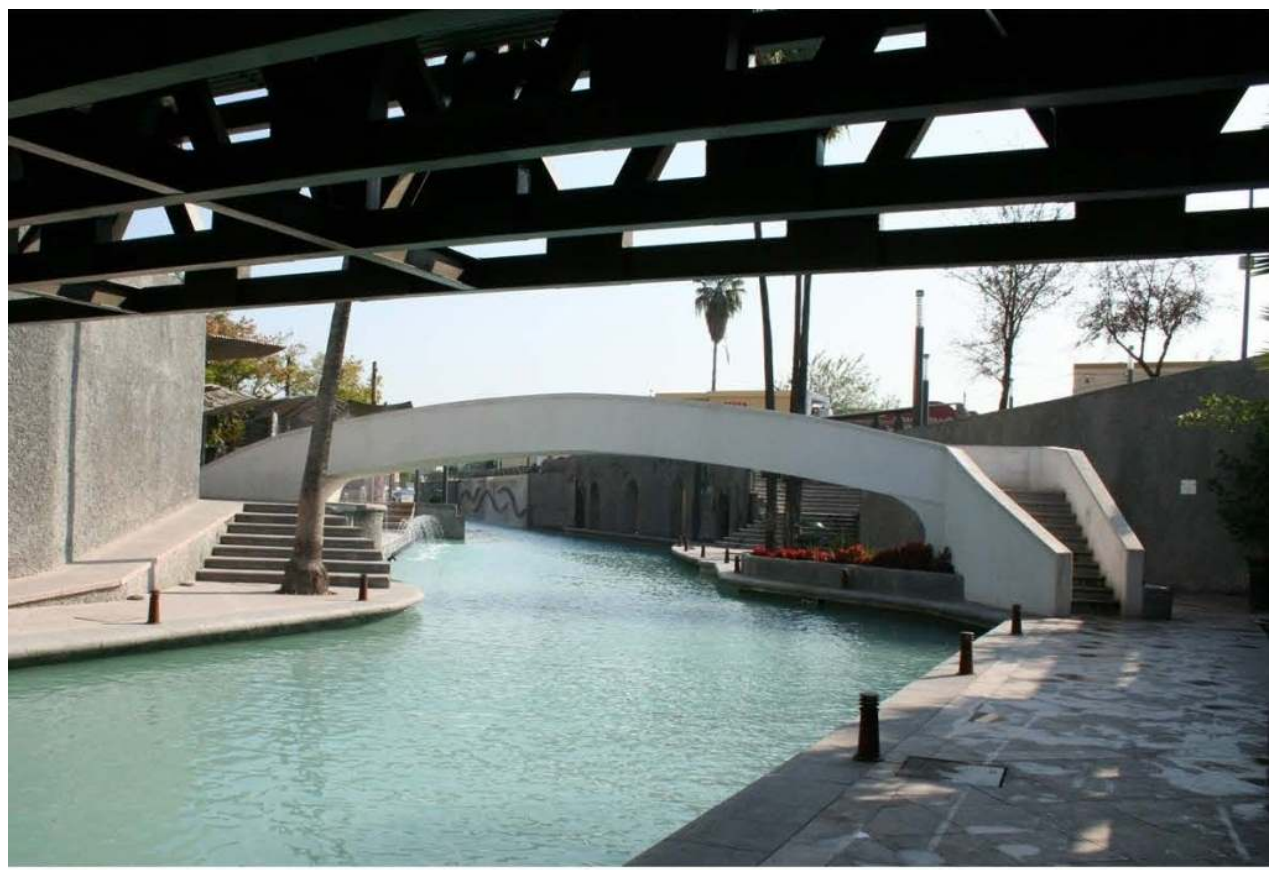

Puente de estilo veneciano sobre el canal (Puente "Platón Sánchez", anejo a la avenida homónima). Foto: R. L.

170

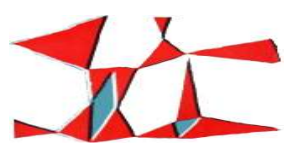

Anuario № 25, Escuela de Historia

Revista Digital № 4, Facultad de Humanidades y Artes, Universidad Nacional de Rosario, 2013

ISSN 1853-8835 

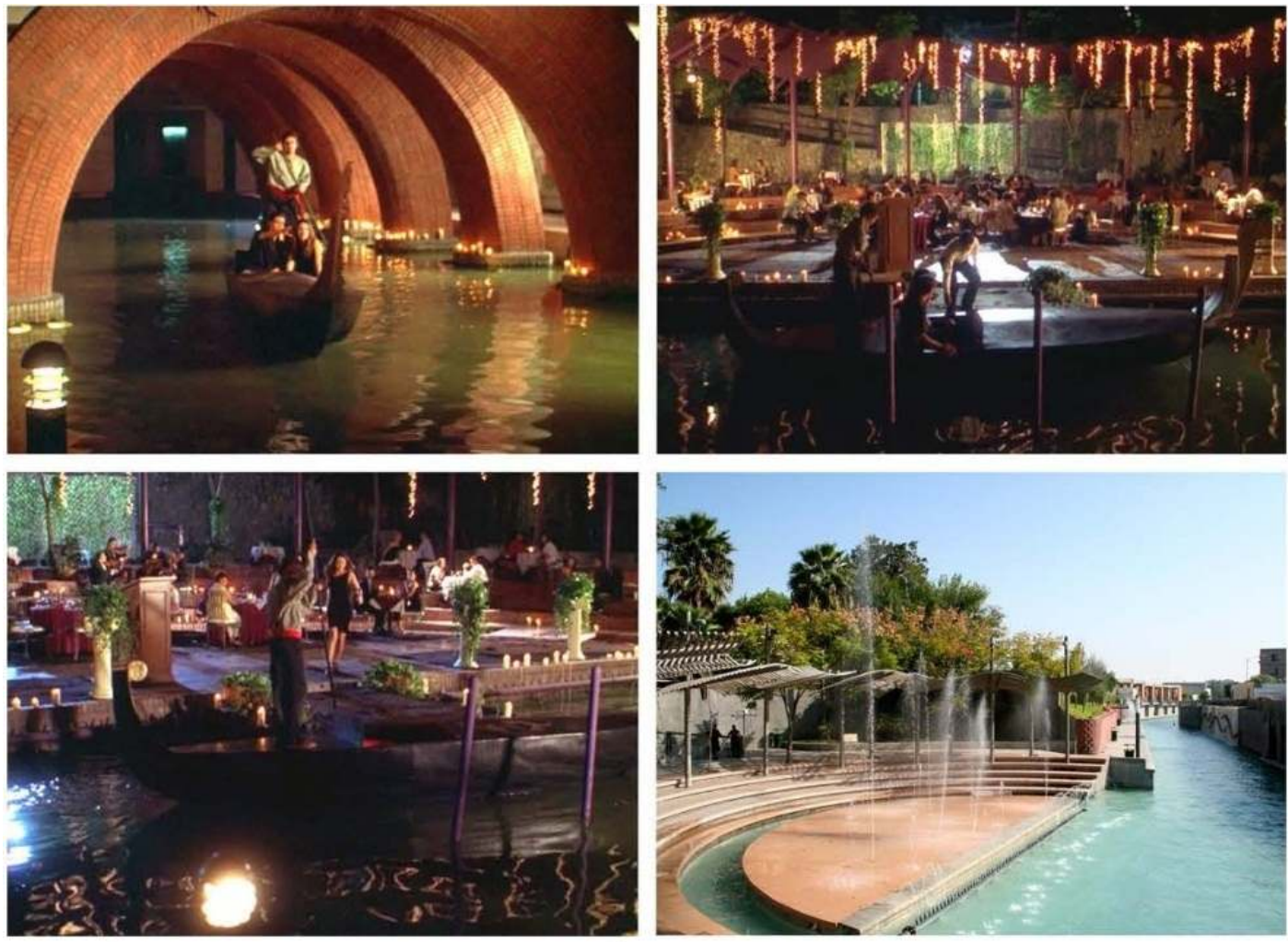

Fotogramas de la película Inspiración (Ángel Mario Huerta, 2001): pasando en góndola bajo el puente de La Purísima y cena romántica en la Fuente Auditorio, convertida en restaurante y atracadero de góndolas. Además, una imagen actual de la propia Fuente Auditorio (Foto: R. L.).

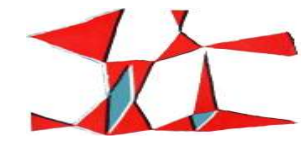

Anuario № 25, Escuela de Historia

Revista Digital № 4, Facultad de Humanidades y Artes, Universidad Nacional de Rosario, 2013

ISSN 1853-8835 
Imagen 6

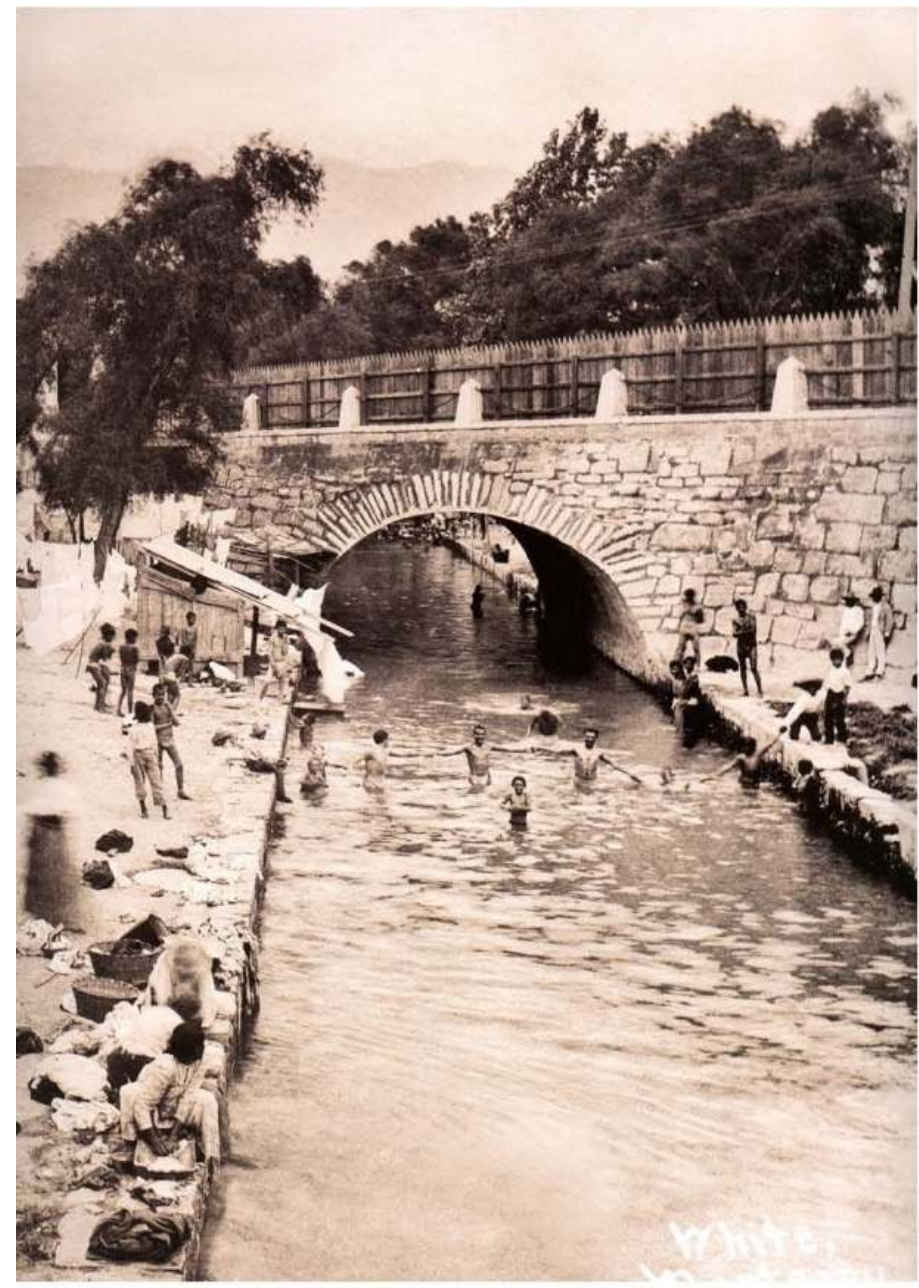

Bañistas en el viejo canalón, junto al antiguo Puente Juárez, sobre la calle Zaragoza. Foto: White (1912, Col. Jaime Toussaint Elosúa).

Recibido: 2 de julio de 2013

Aprobado: 11 de septiembre de 2013

Versión final: 4 de noviembre de 2013

172

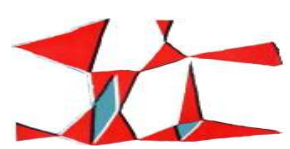

Anuario № 25, Escuela de Historia

Revista Digital № 4, Facultad de Humanidades y Artes, Universidad Nacional de Rosario, 2013

ISSN 1853-8835 